\title{
Pharmacogenetics of rheumatoid arthritis: Potential targets from susceptibility genes and present therapies
}

This article was published in the following Dove Press journal:

Pharmacogenomics and Personalized Medicine

25 March 2010

Number of times this article has been viewed

\section{Darren D O'Rielly \\ Proton Rahman}

Faculty of Medicine, Memorial University of Newfoundland, St. John's, Newfoundland, Canada
Correspondence: Proton Rahman Professor of Medicine (Rheumatology), Memorial University, St. Clare's Mercy Hospital, I54 LeMarchant Rd, St. John's, NL. Canada AIC 5B8

Tel +l 7097775736

Fax +I 7097775212

Email prahman@mun.ca
Abstract: Rheumatoid arthritis (RA) is a chronic heterogeneous autoimmune disorder of unknown etiology resulting in inflammation in the synovium, cartilage, and bone. Genetic factors play an important role in susceptibility to RA as the heritability of RA is between $50 \%$ and $60 \%$, with the human leukocyte antigen (HLA) locus accounting for at least $30 \%$ of overall genetic risk. Outside the major histocompatibility complex (MHC) region, six additional risk loci have been identified and validated including PTPN22, STAT4, PADI4, CTLA4, TNFAIP3$O L I G 3$, and TRAF1/C5. Genetic factors are also important in RA pharmacotherapy due to the gene-dependent activity of enzymes involved in the pharmacokinetics and/or pharmacodynamics of RA medications. Indeed, there is great variability in drug efficacy as well as adverse events associated with any anti-rheumatic therapy and genetics is thought to contribute significantly to this inter-individual variability in response. This review will summarize the genetic factors that have been implicated in the pathogenesis of RA, and how these determinants may factor into the potential pharmacogenetics of this disease. We will also review the therapeutic agents that are currently being utilized or presently being evaluated in the treatment of RA, along with potential pharmacogenetic markers that have been proposed for such medications.

Keywords: rheumatoid arthritis, susceptibility genes, pharmacogenetics

\section{Introduction}

Rheumatoid arthritis (RA) is a systemic inflammatory disease that results in inflammation in the synovium, cartilage and bone. ${ }^{1}$ If RA is not adequately treated in a timely manner, there is significant negative impact to patient health accompanied by a large societal burden. RA typically presents in the sixth decade of life with symmetrical small joint pain and swelling in the hands, feet, and wrists. With disease progression, medium to large size joints such as the shoulder, elbow, knees, and hip become involved. Extra-articular manifestations are common in RA and include features related to vasculitis (eg, rheumatoid nodule, episcleritis, peripheral neuropathy or palpable purpura) and/or lymphocytic infiltrate (eg, sicca symptoms, hypothyroidism, interstitial lung disease, splenomegaly, or lymphadenopathy).

The current therapeutic management of RA includes symptomatic management and early disease modification. Nonsteroidal anti-inflammatory drugs (NSAIDs) and glucocorticoids are first line therapies used for symptomatic relief. However, if oral corticosteroids are instituted, a conscious effort must be made to minimize dosage. In conjunction with the use of NSAIDs, disease-modifying antirheumatic drugs (DMARDs) are promptly initiated in the management of RA. DMARDs attempt to slow down the progression of RA and include: methotrexate (MTX), azathioprine 
(AZA), sulfasalazine (SSZ), hydroxychloroquine (HCQ), and leflunomide (LFA). These agents are either used as monotherapy in a sequential fashion, or more commonly as part of a cocktail with multiple DMARDs. Unless there is a contraindication to MTX, this agent is the DMARD of choice among most rheumatologists. If significant disease activity persists despite an adequate trial of DMARDs, then more targeted biologic therapies such as inhibitors of tumor necrosis factor- $\alpha$ (TNF- $\alpha$ ), interleukin-1 (IL-1), IL-6, co-stimulatory molecule, or B-cells are employed. ${ }^{2}$ The aforementioned roles of various DMARDs and biologic agents serve only as a antecedent to a more detailed discussion of their potential pharmacogenetic targets, presented in upcoming sections.

The etiology of RA is still not fully elucidated. Theories regarding the pathogenesis of RA must address three key elements of the disease: onset of autoimmunity, chronic inflammation, and subsequent joint destruction. ${ }^{3}$ Autoimmunity is manifested by the presence of immunoglobulin G (IgG) antibodies, clinically detectable prior to the onset of RA, which represents the lymphoid phase of the disease. The lymphoid phase is followed by the articular phase which is triggered by poorly understood environmental and biomechanical events in a genetically susceptible host. The environmental factors most frequently associated with RA pathogenesis include smoking and various infectious agents (eg, parvovirus). The persistent inflammation subsequently initiates articular destruction, a process mediated by osteoclasts. The importance of cytokines in the pathogenesis of RA is highlighted by their involvement in every phase of pathogenesis.

In this review, we will summarize the genetic factors and the cytokines that have been implicated in the pathogenesis of RA, and how these determinants may factor into the potential pharmacogenetics of this disease. Moreover, we will review therapeutic agents currently being utilized or presently being evaluated in the treatment of RA, along with potential pharmacogenetic markers that have been proposed for such medications.

\section{Genetics of RA susceptibility}

There is substantive evidence for a genetic basis of RA. There is increased occurrence of disease among first degree relatives (lambdas 2 to 15) and increased concordance of identical twins. The prevalence of RA in the general population varies, but increases among siblings of RA probands. ${ }^{4}$ Based on evidence from studies of monozygotic and dizygotic twins, it is estimated that the heritability of RA is between $50 \%$ and $60 \%,{ }^{5}$ which strongly suggests that genetic factors are indeed critical in RA pathogenesis.
Multiple loci are known to contribute to the risk of developing RA. ${ }^{6-8}$ The most compelling evidence to support a genetic basis is the consistent and reproducible association of RA within the major histocompatibility complex (MHC), particularly the human leukocyte antigen (HLA) alleles. This region accounts for at least $30 \%$ of overall genetic susceptibility to RA. ${ }^{4,6}$ Within the HLA locus, the strongest association is with alleles of $H L A-D R B 1$, but recent evidence indicates that other HLA genes also contribute to genetic risk. Increasingly genes outside the MHC region on different chromosomes (Figure 1) are being indentified regarding the genetics of RA susceptibility (see also Table 1). To date, the most consistent association outside the $\mathrm{MHC}$ region appears to be with a polymorphism in the protein tyrosine phosphatase nonreceptor 22 (PTPN22) gene. ${ }^{6-8,10}$ Other candidate genes have been identified, but the scope of this review will be limited only to the best studied non-MHC variants.

\section{MHC locus is associated with RA pathogenesis}

Association with variations in the MHC or HLA locus on chromosome 6 (6p21.3) was identified over three decades ago, and is the primary locus that has been consistently and reproducibly associated with RA susceptibility across all studied populations. ${ }^{6}$ The class II molecules of the HLA locus are recognized as the most powerful genetic determinants for RA contributing at least $30 \%$ of the total genetic effect. ${ }^{11}$ Numerous classes of $H L A-D R B 1$ alleles known to be associated with RA susceptibility comprise the shared epitope (SE) region (Table 2). ${ }^{7,12,13}$ The $H L A-D R B 1$ alleles of the class II $H L A-D R B 1$ gene encode a conserved sequence of amino acids (ie, QKRAA, QRRAA, or RRRAA) at positions 70 to 74 in the third hypervariable region (HVR3) of the class II DRB1 chain. ${ }^{14}$ The aforementioned $H L A-D R B 1$ alleles and their conserved amino acid sequence are collectively referred to as the shared epitope (SE), which distinguishes disease-associated alleles from those that do not confer risk for RA. ${ }^{14}$

As previously mentioned, extensive evidence exists indicating that the $H L A-D R B 1 \mathrm{SE}$ is strongly associated with susceptibility to RA. ${ }^{14-18}$ While $H L A-D R B 1$ SE alleles confer risk to RA, not all alleles display the same magnitude of association with RA. ${ }^{714,19}$ For example, certain alleles (eg, HLA$D R B 1 * 0401)$ confer a much stronger degree of risk compared with other alleles (eg, $H L A-D R B 1 * 0101) .{ }^{6-8}$ Moreover, certain allelic combinations (eg, HLA-DRB1*0401/*0404) appear to confer a very high risk to RA susceptibility, and even severity of the disease..$^{20}$ The strength of association is influenced 


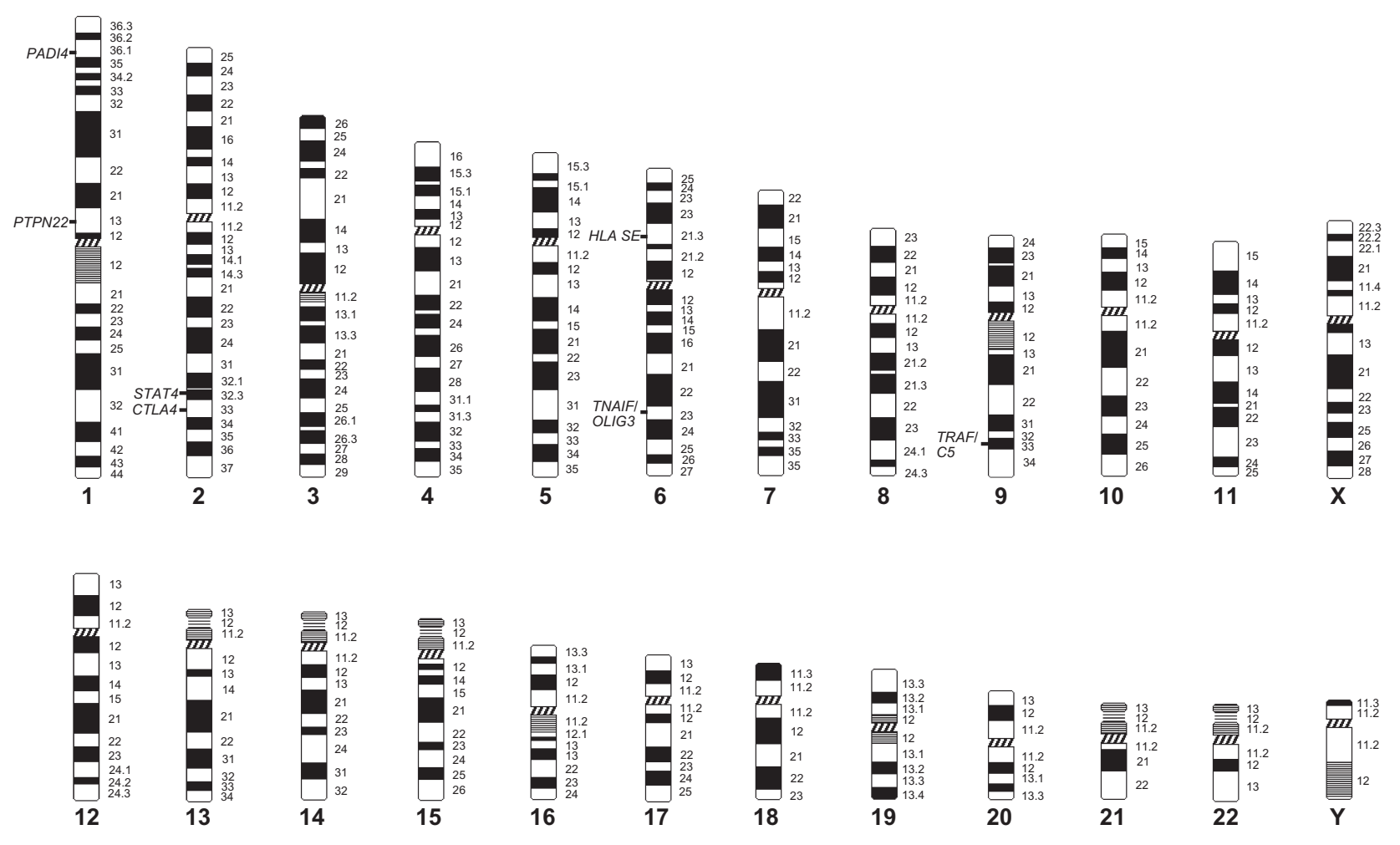

Figure I Location of validated risk genes for rheumatoid arthritis.

by factors including, but not limited to the: 1) frequency and number of SE alleles; 2) amino acid at position 70 to 74 in the HVR3 region of the class II DRB1 chain; and 3) anticitrulline-peptide antibody (ACPA) status. The frequency of the SE alleles varies considerably depending on ethnicity. For example, the HLA-DRB1*0401 and *0404 alleles are predominately associated with RA in Caucasian populations, whereas the $* 0405$ and $* 0101$ alleles are associated with RA in Asian and Jewish populations, respectively. ${ }^{6,21,22}$ In a recent study of French Caucasians, the authors proposed that not only is RA susceptibility conferred by amino acid residues at positions 72 to 74 (ie, RAA), but that the association strength is modulated by amino acid residues at positions 70 and 71 (Table 2) ${ }^{23}$ This hypothesis and proposed classification scheme has been subsequently supported by findings in other populations. ${ }^{13,24,25}$ However, only a single study has investigated the relevance of this new HLA-DRBI classification in terms of RA susceptibility on both Caucasian and non-Caucasian cohorts. ${ }^{26}$

Table I Genetic variants demonstrating strong susceptibility to rheumatoid arthritis

\begin{tabular}{|c|c|c|c|c|c|c|}
\hline Gene/Locus & $\begin{array}{l}\text { Number of RA } \\
\text { patients }\end{array}$ & OR & $95 \% \mathrm{Cl}$ & $P$ value & Ethnicity & Ref. \\
\hline \multirow[t]{2}{*}{ HLA-DRB I SE } & 689 & 3.0 & $2.2-4.2$ & $3.0 \times 10^{-9}$ & Caucasian & 31 \\
\hline & 2,204 & 1.9 & $1.4-2.8$ & $<0.05$ & Asian & 9 \\
\hline PTPN22 & 2370 & 1.6 & $1.4-1.8$ & $4.8 \times 10^{12}$ & Caucasian & 37 \\
\hline \multirow[t]{2}{*}{ STAT4 } & 16,088 & 1.3 & I.2-I.4 & $<0.001$ & Caucasian & 49 \\
\hline & 16,088 & 1.2 & I.I-I.3 & $<0.001$ & Asian & 49 \\
\hline \multirow[t]{2}{*}{ PADI4 } & 5,591 & 1.1 & I.0-I.I & 0.72 & Caucasian & 71 \\
\hline & 3,713 & 1.3 & I.2-I.4 & $<0.0001$ & Asian & 64 \\
\hline CTLA4 & 2370 & 1.1 & $1.0-1.2$ & 0.004 & Caucasian & 37 \\
\hline TNFAIP3-OLIG3 & 3962 & 1.2 & $1.1-1.3$ & $2.6 \times 10^{-6}$ & Caucasian & 91 \\
\hline TRAFI/C5 & 1522 & 1.4 & $1.2-1.5$ & $2.8 \times 10^{-8}$ & Caucasian & 95 \\
\hline
\end{tabular}

Abbreviations: HLA-DRBI SE, major histocompatibility complex, class II, DR beta I; PTPN22, protein tyrosine phosphatase, non-receptor type 22 (lymphoid); STAT4, signal transducer and activator of transcription 4; PADI4, peptidyl arginine deiminase, type IV; CTLA4, cytotoxic T-lymphocyte-associated protein 4;TNFAIP3-OLIG3, tumor necrosis factor, alpha-induced protein 3/oligodendrocyte transcription factor 3;TRAFI/C5,TNF receptor associated factor/complement component 5. 
Table 2 A new scheme remodeling the HLA-DRBI shared epitope classification in rheumatoid arthritis

\begin{tabular}{llll}
\hline Allele classification & HLA-DRBI susceptibility allele & Amino acid sequence & Genetic risk to RA \\
\hline $\mathrm{S}_{2}$ & $* 0401$ & Q-K-RAA & High \\
& $* 1303$ & D-K-RAA & Intermediate \\
$\mathrm{S}_{3 \mathrm{P}}$ & $* 0101, * 0102, * 0404, * 0405, * 0408$ & Q-R-RAA & \\
& $* 1001, * 1402, * 1406$ & R-R-RAA & Low \\
$\mathrm{S}_{1}$ & $* 1501, * 1502, * 1503$ & Q-A-RAA & \\
& $* 0103, * 0402, * 1102, * 1103, * 1301, * 1302$ & D-E-RAA & \\
$\mathrm{S}_{3 \mathrm{D}}$ & $* 1202, * 16$ & D-R-RAA & \\
\hline
\end{tabular}

Abbreviations: HLA-DRBI, major histocompatibility complex, class II, DR beta I; RA, rheumatoid arthritis.

In that study ( $\left.\mathrm{n}_{\text {cases/controls }}=759 / 789\right)$, a positive association with RA susceptibility was demonstrated for $\mathrm{S}_{2}$ allele carriers (odds ratio $[\mathrm{OR}]=2.1,95 \%$ confidence interval $[\mathrm{CI}]: 1.5-3.0$; $P<0.0001)$ and $\mathrm{S}_{3} \mathrm{P}$ allele carriers $(\mathrm{OR}=2.74,95 \% \mathrm{CI}$ : 2.0-3.7; $P<0.0001) .{ }^{26}$

The RA susceptibility associated with the HLA-DRB1 SE appears to be limited to a subset of patients who have ACPApositive and not ACPA-negative RA. ${ }^{12,27-31}$ For example, in the largest cohort studied to date, the presence of any HLA-DRBI SE allele was strongly associated with an ACPA-positive phenotype $\left(\mathrm{OR}=3.0,95 \% \mathrm{CI}: 2.2-4.2 ; P=3.0 \times 10^{-9}\right){ }^{31}$ That $H L A-D R B 1$ SE confers risk specifically to ACPA and that these antibodies are present in approximately $70 \%$ of RA patients ${ }^{32}$ explains, at least in part, an association between these alleles and susceptibility to RA and perhaps more importantly, suggests a difference in the pathology between ACPA-positive and ACPA-negative RA.

In addition to affecting disease susceptibility, the HLA SE appears to be important in onset, progression, and severity of RA. In a large European cohort, the presence of any HLA SE allele was associated with an average 3.6 years earlier diagnosis compared with absence of $H L A$ SE; ${ }^{31}$ a finding replicated in an American cohort. ${ }^{33}$ Moreover, large differences were identified in rates of erosion progression between ACPA-positive and ACPA-negative RA with respect to the HLA SE. ${ }^{12}$ The strength of this association appears to be dependent on the number of copies of the SE allele (two copies: $\mathrm{OR}=11.8, P<0.0001$; one copy: $\mathrm{OR}=4.4$, $P<0.0001)$. This finding combined with the report that ACPA-positive has a more aggressive clinical course than ACPA-negative RA, ${ }^{34}$ strongly implies that this locus not only plays a significant role in RA susceptibility, but also is important in the severity of RA. Thus, in the clinical setting, these determinants (ie, SE alleles or ACPA status) will likely translate into poor therapeutic impacts by virtue of the fact that these subset of patients have a greater burden of inflammatory disease.

\section{PTPN22 is associated with RA pathogenesis}

The tyrosine phosphatase nonreceptor 22 (PTPN22) gene, located on chromosome 1 (1p13), was the first non- $H L A$ gene associated with RA. ${ }^{35}$ Specifically, the minor allele of a nonsynonymous $1858 \mathrm{C}>\mathrm{T}$ single nucleotide polymorphism (SNP; rs2476601), results in an amino acid change from R620W in the PTPN22 gene. ${ }^{35}$ Outside of the HLA region, this variant exhibits the strongest and most robust association with RA (Table 1). The well studied associations with HLA-DRB1 and PTPN22 explain about $50 \%$ of the genetic contribution to RA disease susceptibility. ${ }^{36} \mathrm{~A}$ meta-analysis of 13 RA studies $\left(n_{\text {cases/controls }}=2370 / 1757\right)$ revealed a strong association of the T-allele genotype with the development of RA (OR $=1.6$, 95\% CI: $1.4-1.8 ; P=4.8 \times 10^{12}$ ), and an earlier age at disease onset. ${ }^{37}$ Similar to HLA-DRB1, PTPN22 is strongly associated with ACPA-positive (OR $=1.43,95 \%$ CI: $1.2-1.7 ; P=0.0001)$, but not ACPA-negative (OR $=1.0,95 \% \mathrm{CI}: 0.8-1.3 ; P=0.73$ ) $\mathrm{RA} ;{ }^{37}$ a finding that strengthens the theory that ACPA-positive and ACPA-negative RA have different pathologies. The greater risk allele frequency present in Caucasian RA populations $(\mathrm{OR}=1.7,95 \% \text { CI: } 1.2-2.2 ; P<0.0001)^{35}$ is consistent with the extensive evidence confirming that the PTPN22 variant is associated with RA in all populations of European or North American descent. ${ }^{35,37-44} \mathrm{~A}$ lack of association of PTPN22 in Asian and African populations is reflected by the absence or very low frequency of this risk allele in that demographic. ${ }^{35}$

Similar to the SE, the PTPN22 appears to be important in onset, progression, and severity of RA. In a large European cohort, the presence of any PTPN22 variant was associated with an average 4.2 years earlier diagnosis compared with absence of a variant; ${ }^{31}$ a finding subsequently replicated in another large Caucasian cohort. ${ }^{37}$ In contrast to the HLA SE, PTPN22 does not appear to be associated with an erosive phenotype ${ }^{31}$ This finding combined with the report that ACPA-positive has a more aggressive clinical course than ACPA-negative RA, ${ }^{34}$ suggests that PTPN22 not only plays a significant role in RA susceptibility, 
but may also be important in severity of RA; an effect similarly reported for the HLA SE. Likewise, the presence of the PTPN22 variant may influence the outcome of various therapeutic agents in RA. Of course, such speculation requires further confirmation.

PTPN22 which encodes the intracellular protein lymphoid tyrosine phosphatase (LYP), a powerful inhibitor of T-lymphocyte activation, plays a critical role in T-lymphocyte antigen receptor (TCR) signaling pathway. ${ }^{45}$ The $P N P T 22$ polymorphism is a gain-of-function variant resulting in greater phosphatase activity which elevates the activation of T-lymphocytes and confers enhanced inhibition of activation. ${ }^{46,47}$ Interestingly, T-lymphocytes expressing the PTPN22 polymorphism produce less IL-2 in response to T-lymphocyte signaling compared to wildtype controls. ${ }^{46,47}$ Such a variant which enhances inhibition of T-lymphocyte activation may result in weaker signaling and failure to effectively remove auto-reactive T-lymphocytes, which could explain, at least in part, its relevance to RA. ${ }^{7}$

\section{STAT4 is associated with RA pathogenesis}

The signal transducer and activator of transcription 4 (STAT4) gene, located on chromosome $2(2 q 32.2-q 32.3)$ is another non$M H C$ gene associated with RA pathogenesis. ${ }^{48}$ Specifically, a SNP was identified at position 274 (-23582G $>$ A; rs7574865) within the third intron of the STAT4 gene. ${ }^{48}$ Four polymorphisms in tight linkage disequilibrium (ie, rs11889341, rs7574865, rs8179673, and rs10181656) form a susceptibility haplotype which is tagged by the T allele (rs7574865), have the strongest reported association with RA. ${ }^{48} \mathrm{~A}$ meta-analysis conducted on 15 studies $\left(\mathrm{n}_{\text {cases/controls }}=16,088 / 16,509\right)$ revealed an significant association between RA and the STAT4 variant (rs7574865) in both Caucasians (OR $=1.3,95 \%$ CI: $1.2-1.4 ; P<0.001)$ and Asians $(\mathrm{OR}=1.2,95 \% \mathrm{CI}: 1.1-1.3 ; P<0.001) .{ }^{49}$ The association of STAT4 variant (rs7574865) with RA was validated in patients from European, North American, and Asian descent. ${ }^{49-54}$ Europeans appear to have the lowest (21.4\%) and Asians the highest (32.0\%) prevalence of the rs 7574865 variant among the populations studied. ${ }^{49}$ Stratification of RA patients according to the presence of ACPA antibody revealed a statistically significant association between the rs 7574865 variant and RA in both ACPA-positive and ACPA-negative RA patients versus controls. ${ }^{54,55}$ That STAT4 confers risk specifically to ACPA, that these antibodies are present in approximately $70 \%$ of RA patients, ${ }^{32}$ and that a similar finding has been demonstrated with SE and PTPN22, explains, at least in part, an association between STAT4 and susceptibility to RA and again strongly indicate a difference in the pathology between ACPA-positive and ACPA-negative RA.
The JAK/STAT pathway is the signaling target of a multitude of cytokines that are thought to play biologically significant roles in rheumatoid synovial inflammation. ${ }^{56}$ Specifically, STAT4, which encodes STAT4, transmits signals induced by several key cytokines, including IL-12, IL-23, and type I interferons (IFNs). ${ }^{57}$ Activated STAT4 transcribes specific genes including interferon- $\gamma$, and plays a critical role in the development of type 1 helper T (Th1) lymphocyte response thought to drive the chronic autoimmune response. ${ }^{58-60}$ STAT4 has also been implicated in the differentiation of Th17 cells; an effect dependent in part on the activity of IL-23. ${ }^{61}$ Thus, the JAK/STAT pathway with its many interactions, including various inflammatory cytokines $^{61,62}$ may explain, at least in part, the association of the STAT4 gene with chronic inflammatory disorders including RA.

\section{PADI4 is associated with RA pathogenesis}

The peptidylarginine deiminase 4 (PADI4) gene, located on chromosome 1 (1p36), is known to be associated with RA, particularly in Asian populations. ${ }^{63,64}$ The strongest association has been demonstrated for a SNP located in intron 3 (341-15A > T) of PADI4, called PADI4_94 (rs2240340) and a recent meta-analysis revealed a significant association between RA and the PADI4_94 SNP in Asian populations $(\mathrm{OR}=1.3,95 \% \mathrm{CI}: 1.2-1.4 ; P<0.0001) .{ }^{64}$ In contrast, findings in cohorts of European ancestry have been inconsistent. ${ }^{37,63-66,69,70}$ Whereas PADI4_94 was found to be associated with RA in North American and German populations, studies in Spanish, Swedish, and UK populations reported no evidence for association of PADI4 with RA. ${ }^{37,65}$ Analysis of data collected in the largest study performed to date $\left(\mathrm{n}_{\text {cases/controls }}=\right.$ $5,591 / 13,638)$ gave an overall OR of 1.01 (95\% CI: 1.0-1.1; $P=0.72$ ), indicating that PADI4_94 genotype is not associated with RA in European Caucasian descent. This result is supported by a recent meta-analysis which confirmed a lack of association between PADI4_94 genotype and RA in people of European descent $(\mathrm{OR}=1.1,95 \% \mathrm{CI}: 1.0-1.1 ; P=0.12) .{ }^{71}$ This meta-analysis contrasted two earlier meta-analyses which suggested that the PADI4_94 polymorphism confers susceptibility to RA in those of European descent (OR $=1.1$; 95\% CI: $1.0-1.2 ; P=0.0096$ ), albeit to a lesser degree than in Asian subjects. ${ }^{72,73}$ The discrepancy between studies of Caucasian descent can be explained, at least in part, by previous studies being underpowered to detect an OR of this level, thus producing false-positive results. ${ }^{71}$ Therefore, PADI4_94 may be in LD with the true disease associated allele in Asian but 
not Caucasian populations. ${ }^{71}$ A possible explanation for the difference between RA patients from Asian and European descent may be that PADI4 is associated only with a subgroup of RA patients. Specifically, the association between PADI4 genotype and RA may be restricted to patients with more severe disease. ${ }^{74}$ Unlike the HLA-DRB1, PTPN22, and STAT4 genes, there is growing evidence that $P A D I 4$ polymorphisms play a role in the development RA in Asian populations independent of ACPA status. This observation suggests that the aforementioned genes may affect RA susceptibility via different but possibility convergent mechanisms. This does not preclude the possibility that PADI4 interacts with and modulates the activity of ACPA-dependent genetic factors such as the HLA SE.

The PADI4 gene encodes the type 4 peptidylarginine deiminase enzyme, which catalyses the post-translational modification of arginine to citrulline, generating citrullinated proteins. ${ }^{75}$ The mechanism by which PADI4 genotype may influence RA susceptibility has not yet been elucidated. While the link between synovial intracellular citrullinated proteins and ACPA status emphasizes the role of deimination of synovial proteins in RA, there is no compelling evidence supporting PADI4 genotypes correlating with ACPA levels or ACPA-positive disease in particular. Antibodies to these citrillinated peptides are highly specific for RA and often precede the development of disease, suggesting a critical role in RA pathogenesis. ${ }^{63}$ In addition, PADI4 mRNA was detected in hematological cells and pathological synovial tissues, and is significantly overexpressed in the blood of RA patients. ${ }^{76,77}$ Moreover, anti-PAD-4 auto-antibodies were associated with the PADI4 susceptibility haplotype. ${ }^{71}$ Collectively, these reports suggest that critical link between the PADI4 gene and the pathogenesis of RA in Asian populations.

\section{CTLA4 is associated with RA pathogenesis}

The cytotoxic T lymphocyte antigen 4 (CTLA4) gene, which is located on chromosome 2 (2q33), has been investigated frequently in relation to RA. While other polymorphisms within the CTLA4 gene appear to be associated with RA, ${ }^{78-80}$ an G $>$ A SNP in the $3^{\prime}$ untranslated region (CT60; rs3087243) has received a more thorough investigation, especially in European populations. ${ }^{37,52,80-82}$ Although previous case-control studies in various populations have suggested a possible association of CTLA4 alleles with RA, the results of these studies are often inconclusive and are sometimes contradictory. A large cohort $\left(\mathrm{n}_{\text {cases/controls }}=2,370 / 1,757\right)$ from the North American Rheumatoid Arthritis Consortium (NARAC) and the Swedish Epidemiological Investigation of Rheumatoid Arthritis (EIRA) collections, provided support for an association of CTLA4 (CT60 allele) with the development of RA, but only in the NARAC cohort $(\mathrm{OR}=1.1,95 \% \mathrm{CI}: 1.0-1.2$; $P=0.004) .{ }^{37}$ When those results were combined with previously published data for CTLA4, it demonstrated continued evidence of association with RA (OR $=1.1,95 \%$ CI: $1.0-1.2$; $P=0.01) .{ }^{37}$ These earlier results correlated well with a recent meta-analysis which confirmed an association of CTLA4 gene polymorphism with RA in Caucasians $\left(\mathrm{OR}=0.9, P=1.8 \times 10^{-3}\right)$ which also revealed that CTLA4 enhanced the development of ACPA-positive as compared with ACPA-negative RA. ${ }^{52}$ Similar to HLA-DBR1 SE and PTPN22, these reports clearly indicate that CTLA4 influences the development of RA only in ACCP-positive patients and is further evidence pointing to a divergence in pathology dependent on ACCP status.

The CTLA4 gene, which encodes the CTLA4 protein, plays an important role in downregulation of T-cell activation. ${ }^{83}$ Full activation of T-lymphocytes requires both the recognition of an antigen bound to HLA and a co-stimulatory signal between CD80 or CD86 on the antigen-presenting cell and CD28 on the T-lymphocyte. ${ }^{84-86}$ CTLA4 protein expressed on T-lymphocytes as CTLA4 binds to CD80/CD86, may influence susceptibility to RA by inhibiting this co-stimulatory signal. However, the exact mechanism by which CTLA4 genotype may influence RA susceptibility still remains to be determined.

The importance of CLTA4 to RA pathogenesis is indicated by the development of a soluble fusion protein (ie, abatacept) that consists of the extracellular domain of CTLA-4 linked to the modified Fc (hinge, $\mathrm{CH} 2$, and $\mathrm{CH} 3$ domains) portion of human immunoglobulin G1 (IgG1). ${ }^{84}$ Abatacept inhibits T-lymphocyte activation by binding to CD80 and CD86, thereby blocking interaction with CD28. This interaction provides a co-stimulatory signal necessary for full activation of T-lymphocytes. ${ }^{84-86}$ Abatacept has been shown to be effective in treating RA and is indicated in the treatment of moderate to severe RA and active polyarticular juvenile idiopathic arthritis. ${ }^{84-86}$

\section{TNFAIP3-OLIG3 is associated with RA pathogenesis}

This association locus was first identified in a GWAS ${ }^{36}$ and has been subsequently confirmed in multiple Caucasian and Asian cohorts. ${ }^{87-92}$ Specifically, a study of 3962 RA patients and 3531 healthy controls demonstrated strong association $\left(\mathrm{OR}=1.2 ; 95 \% \mathrm{CI}: 1.1-1.3 ; P=2.6 \times 10^{-6}\right)$ with a variant (rs6920220) in an intergenic region of chromosome 6q23 region between oligodendrocyte linear transcription factor 3 
(OLIG3) and TNF- $\alpha$-induced protein 3 (TNFAIP3). ${ }^{91}$ The validity of this study has been confirmed by a recent metaanalysis of seven studies investigating the association of the TNFAIP3-OLIG3 region with RA, which indicated a strong association of the variant rs6920220 (OR $=1.2,95 \% \mathrm{CI}$ : $\left.1.2-1.3 ; P=7.9 \times 10^{-17}\right) .{ }^{92}$ Since the TNFAIP3 gene acts as a negative regulator of the transcription factor nuclear factor- $\kappa \mathrm{B}(\mathrm{NF} \kappa \mathrm{B})$ in response to TNF- and toll-like receptor activation, ${ }^{93,94}$ it is an attractive RA susceptibility candidate gene. Unfortunately, currently there is no therapeutic agent specifically targeting this molecule.

\section{TRAF I/C5 is associated with susceptibility to RA}

This association locus was first identified in the same GWAS that identified the TNFAIP3-OLIG3 locus, ${ }^{36}$ and has been subsequently confirmed in a large Caucasian cohort. ${ }^{95}$ There is strong evidence of association with a variant (rs3761847) in a region of chromosome $9 \mathrm{q} 33-34(\mathrm{OR}=1.4,95 \% \mathrm{CI}$ : $1.2-1.5$; $\left.P=2.8 \times 10^{-8}\right)$; a region spanning the genes for TRAF1 and C5. ${ }^{95}$ Both TRAF1 and $C 5$ are biologically plausible contributors of RA susceptibility. The product of TRAF1 appears to act as a negative regulator of signals mediated through TNF receptors and T-lymphocyte receptors, whereas C5 is an important component of the complement pathways, thought to play a role in articular inflammation in RA. ${ }^{95}$

\section{Other RA susceptibility genes}

In addition to the already described associations, other genes previously identified by GWAS are highly suggestive for an association with RA susceptibility. Recently, relatively large cohort studies have strengthened the association of multiple highly suggestive genes with RA susceptibility, especially with genes involved in pathways important to RA pathogenesis. In particular, there is growing evidence that the NFкB signaling pathway may be a critical transcription factor implicated in a variety of cellular responses to stimuli, including inflammation. ${ }^{96}$ To date, multiple genes known to interact with NFkB signaling have been proposed to be associated with RA susceptibility (eg, CD40, CD244, CDK6, CCL21, PRKCQ, TNFRSF14, PIP4K2C,IL-1B, IL-2RB, and IL-2RA). For these genes, replication in large population cohorts is required before validation as true RA risk alleles.

\section{Gene expression studies in RA}

The cDNA microarray technology enables simultaneous expression of thousands of RNA's transcribed from both known and unknown genes. This technology is helpful for large-scale gene discovery, as it provides diagnostic fingerprints by comparing gene expression patterns in normal and pathological cells in a single experiment. Expression profiling studies in RA cohorts can be categorized in two broad categories: those involved in identifying susceptibility genes and those looking at disease expression in RA. A recent systemic review summarized gene expression studies that was differentially expressed in at least two studies or genes differentially

Table 3 Genes associated with a differential expression pattern in patients with rheumatoid arthritis

\begin{tabular}{|c|c|}
\hline \multicolumn{2}{|c|}{ Differential expression of genes in more than one RA study* } \\
\hline Gene & Location \\
\hline $\begin{array}{l}\text { Cleavage stimulation factor, } 3 \text { pre-RNA, } \\
\text { subunit } 2 \text { (CSTF2) }\end{array}$ & $\mathrm{Xq22.1}$ \\
\hline Solute carrier family genes (SLC7A7, SLC25A4) & $|4 q| 1.2,4 q 35$ \\
\hline Colony-stimulating factor 3 receptor (CSF3R) & Ip35-p34.3 \\
\hline Troponin genes (TNNII,TNNT2,TNNI2,TNNT3) & $|q 31.3-32|,|p| 5.5$ \\
\hline Argninosuccinate lyase (ASL) & $7 c e n-q \mid 1.2$ \\
\hline Tumor protein $\mathrm{p} 53$ (TP53) & $|7 p| 3.1$ \\
\hline Tyrosine kinase (TXK) & $4 p 12$ \\
\hline Ribosomal protein SA (LAMRI) & $3 p 22.2$ \\
\hline Bone morphogenetic protein 8 (BMP8) & $1 p 35-p 32$ \\
\hline Cytokine P450 (CYP3A4) & $7 q 21.1$ \\
\hline Kininogen I (KNGI) & $3 q 27$ \\
\hline SI00 calcium-binding protein $(\mathrm{SI} 00)$ & $|q 2|$ \\
\hline Protein phosphatase 2 (PPP2R3) & $3 q 22.1$ \\
\hline Matrix metalloproteinase (MMP3) & IIq22.3 \\
\hline
\end{tabular}

Differential expression of genes in only one RA study but falling within susceptibility region from previous linkage or association studies*

\begin{tabular}{|c|c|}
\hline Gene & Location \\
\hline Kininogen I (KNGI) & $3 q 27$ \\
\hline Colony-stimulating factor 3 receptor (CSF3R) & Ip35-p34.3 \\
\hline Troponin T type 2 (TNNT2) & $1 \mathrm{q} 32$ \\
\hline Protease subunit beta-type 9 (PSMB9) & $6 p 21.3$ \\
\hline EGF receptor pathway substrate I5 (EPSI5) & $1 \mathrm{p} 32$ \\
\hline Membrane cofactor protein (MCP) & $1 \mathrm{q} 32$ \\
\hline Stomatin (EPB72) & $9 q 34.1$ \\
\hline Interferon regulator factor 4 (IRF-4) & $6 p 25-p 23$ \\
\hline Neutrophil cytosolic factor 4 (NCF4) & $22 q 13.1$ \\
\hline Interleukin 8 (GM-CSF) & $4 q 13-q 21$ \\
\hline Stathmin I (STMNI) & Ip36.I \\
\hline Protein tyrosine phosphatase (PTPRK) & $6 p 22.2-23.1$ \\
\hline AA598840 & Ip34.3 \\
\hline AA487590 & $13 q 12-q \mid 3$ \\
\hline Acyl-coenzyme A thioesterase $7(\mathrm{HBACH})$ & $|p 36.31-p 36.1|$ \\
\hline
\end{tabular}

Notes: Copyright (c) 2008, BMJ.Adapted and summarized from Toonen EJ, Barrera P, RadstakeTR, et al. Gene expression profiling in rheumatoid arthritis: current concepts and future directions. Ann Rheum Dis. 2008;67(I2):1663-1669. 
expressed in at least one study but located within a genetic linkage or association region (Table 3). ${ }^{97}$

With respect to disease expression, microarray studies of synovial biopsies compared expression of early and long standing rheumatoid arthritis. ${ }^{98}$ In that study, the authors identified several gene clusters and distinct molecular signatures specifically expressed during early or late RA, suggesting that different mechanisms are in play at various stages of RA.

\section{Pharmacogenetics of RA}

There is great variability in drug efficacy as well as adverse events with almost any antirheumatic therapy. Profiling for individual genetic variability holds great promise in treating rheumatic conditions. The identification of such variants has the potential to improve management of patient care by identifying which patients should avoid a specific drug and which patients should be administered a modified dose. A suitable approach in implementing such a strategy could potentially reduce medical costs and improve the overall process and success of drug therapy. ${ }^{99}$ This section of the paper will serve to highlight the current landscape of genetic targets for RA pharmacotherapy.

\section{NSAIDs}

Nonsteroidal anti-inflammatory drugs (NSAIDs) continue to be the mainstay of therapy for symptomatic relief. NSAIDs are primarily metabolized by the polymorphic CYP2C9 enzyme with a minor contribution from the CYP2C8 enzyme. Functionally important SNPs associated with decreased catalytic activities have been identified in both enzymes, especially for CYP2C9, which vary in frequency according to ethnicity. ${ }^{100}$ The metabolic capacities of the CYP2C9*2 and *3 alleles are approximately $70 \%$ and $3 \%$ to $11 \%$ compared to the wildtype allele, respectively. ${ }^{100}$ While NSAIDs are usually well tolerated for short periods of time, chronic use can lead to gastrointestinal complications (eg, ulcer formation, perforations, and bleeding), and renal toxicity. ${ }^{101,102}$ Gene-based dosing for NSAIDs aimed at reducing the occurrence of ADRs is hindered by differing metabolic rates among various NSAIDs and the involvement of additional metabolizing enzymes (eg, CYP2C8). Individuals carrying the gene variants $C Y P 2 C 8 * 3$ (rs11572080; rs10509681), CYP2C9*2 (rs1799853) or CYP2C9*3 (rs1057910) show increased risk of developing acute gastrointestinal bleeding with NSAID therapy. ${ }^{103}$ Specifically, significantly higher frequencies of $C Y P 2 C 9 * 1 / * 3$ (34.6\% vs 5.8\%, OR = 12.9, 95\% CI: $2.9-57.9 ; P<0.001)$ and $C Y P 2 C 9 * 1 / * 2(26.9 \%$ vs $15.4 \%, \mathrm{OR}=3.8,95 \% \mathrm{CI}$ :
$1.1-13.2 ; P=0.036)$ were identified in bleeding versus control patients. ${ }^{103}$ However, it is currently unknown whether parent drugs or products of alternative metabolic pathways are responsible for bleeding.

\section{Glucocorticoids}

Glucocorticoids, such as prednisone, have been widely used in the treatment of RA by providing rapid symptomatic relief of pain and swelling. ${ }^{104,105}$ Although glucocorticoids inhibit inflammation, they also induce the expression of macrophage migration inhibitory factor (MIF), which in turn, possesses the unique ability to override the inhibitory effect of glucocorticoids on immune and inflammatory responses. ${ }^{106}$ The MIF $(-173 \mathrm{G}>\mathrm{C})$ variant has recently been linked to clinical response in numerous inflammatory conditions. ${ }^{107-111}$ For example, in juvenile RA patients carrying a MIF (-173C) allele, the number of DMARDs required for the treatment was increased, the duration of corticosteroid treatment was significantly longer, and the number of joints with active arthritis was significantly higher. ${ }^{110}$ Such a strong predictor of poor treatment outcome in juvenile RA patients would suggest a similar effect in RA patients. A study which investigated this possibility failed to demonstrate a strong association of MIF $(-173 \mathrm{G}>\mathrm{C})$ with clinical response to glucocorticoids in RA. ${ }^{12}$ However, due to the small sample size and thus, lack of power, this finding requires replication in larger cohorts. In the future, therapeutic MIF antagonism may therefore provide a specific means of 'steroid sparing'.

\section{Methotrexate}

Methotrexate (MTX) is a very effective therapy in treating RA and is the initial disease modifying agent for the majority of rheumatologists. Thus, the majority of patients with RA would have been evaluated on methotrexate at some point in their course. ${ }^{113}$ The ADRs associated with MTX range from mild and self-limiting (eg, mucositis, gastrointestinal intolerance) to more severe (eg, hematopoietic suppression, hepatotoxicity, pulmonary toxicity). Both the efficacy and toxicity of MTX is governed by transport (eg, RFC-1, MDR1) and metabolizing enzymes (eg, MTHFR, TYMS, DHFR, ATIC, etc). Variants exist within the genes encoding these enzymes which affect efficacy and/or toxicity of MTX and explains at least in part, the inter-individual variability in response to MTX. Several polymorphisms of genes encoding the MTX signaling pathway have been investigated in relation to efficacy and toxicity (Table 4); however, only the most studied variants will be discussed here in detail. RFC-1 transports folate and MTX into cells and some stud- 
Table 4 Candidate gene polymorphisms associated with either efficacy and/or toxicity of MTX pharmacotherapy in rheumatoid arthritis patients

\begin{tabular}{|c|c|c|c|c|}
\hline Gene & Variant & Function & Effect on MTX therapy & Ref. \\
\hline \multicolumn{5}{|c|}{ Variants affecting transport of MTX } \\
\hline \multirow[t]{2}{*}{ RFC-I } & $80 \mathrm{G}>\mathrm{A}$ & $\begin{array}{l}\text { Minimal effect on transport } \\
\text { of folate and MTX into cells }\end{array}$ & $\begin{array}{l}\text { AA genotype associated with } 3.7 \text {-fold greater response } \\
(95 \% \mathrm{Cl}: 1.7-9.1, P<0.01)\end{array}$ & 114 \\
\hline & & & $\begin{array}{l}\text { GA/AA genotype associated with increased risk } \\
\text { for overall MTX toxicity }(\mathrm{OR}=3.574,95 \% \mathrm{Cl}: \mathrm{I} . \mathrm{I}-12.0 \text {; } \\
P=0.039)\end{array}$ & 118 \\
\hline$M D R I$ & $3435 \mathrm{C}>\mathrm{T}$ & ? & $\begin{array}{l}\text { TT genotype associated with a higher remission } \\
\text { probability }(\mathrm{OR}=4.65,95 \% \mathrm{Cl} \text { : I.7-13.0; } P=0.003)\end{array}$ & $118-120$ \\
\hline \multicolumn{5}{|c|}{ Variants affecting intracellular metabolism of MTX } \\
\hline \multirow[t]{9}{*}{ MTHFR } & $677 \mathrm{C}>\mathrm{T}$ & $\begin{array}{l}\text { Decreased reduction of } \\
5,10-\mathrm{CH}_{2}-\mathrm{THF} \text { to } 5-\mathrm{CH}_{3}-\mathrm{THF}\end{array}$ & $\begin{array}{l}\text { CT/TT genotype associated with increased ADRs } \\
(\mathrm{RR}=2.0,95 \% \mathrm{Cl}: \mathrm{I} . \mathrm{I}-3.7)\end{array}$ & 126 \\
\hline & & & $\begin{array}{l}\mathrm{CT} / \mathrm{TT} \text { genotype associated with higher rate } \\
\text { of MTX toxicity }(\mathrm{RR}=1.2,95 \% \mathrm{Cl}: 1.0-1.5 ; P<0.05)\end{array}$ & 128 \\
\hline & & & No effect on efficacy & 126,127 \\
\hline & & & CC genotype associated with greater response in early RA & 117 \\
\hline & $1298 \mathrm{~A}>\mathrm{C}$ & $\begin{array}{l}\text { Decreased reduction of } \\
5,10-\mathrm{CH}_{2}-\mathrm{THF} \text { to } 5-\mathrm{CH}_{3}-\mathrm{THF}\end{array}$ & $\begin{array}{l}\text { AC/CC genotype required lower doses of MTX } \\
(\mathrm{RR}=2.2,95 \% \mathrm{Cl}: 1.2-4.1, P<0.05)\end{array}$ & 128 \\
\hline & & & $C C$ genotype associated with fewer ADRs & 127,129 \\
\hline & & & $\begin{array}{l}\text { AC/AA genotype associated with higher rate of } \\
\text { MTX toxicity }(O R=15.9,95 \% \mathrm{Cl}: 1.5-167.0 ; P=0.021)\end{array}$ & 127 \\
\hline & & & AA genotype associated with greater response in early RA & 117 \\
\hline & & & AC genotype associated with more ADRs & 117 \\
\hline \multirow[t]{2}{*}{ TYMS } & $28 \mathrm{bp}$ tandem repeat & $\begin{array}{l}\text { Decreased conversion } \\
\text { of } \mathrm{CH}_{2} \text {-THF to DHF }\end{array}$ & $\begin{array}{l}\text { Alleles with three repeats associated } \\
\text { with MTX resistance }\end{array}$ & 114,132 \\
\hline & & & $\begin{array}{l}\text { Alleles with only two repeats associated } \\
\text { with improved response }\end{array}$ & 114,132 \\
\hline \multirow[t]{2}{*}{ ATIC } & $347 C>G$ & $\begin{array}{l}\text { Decreased de novo purine } \\
\text { synthesis }\end{array}$ & GG genotype associated with improved response & 130,114 \\
\hline & & & GG genotype associated with ADRs & $|3|$ \\
\hline
\end{tabular}

Abbreviations: RFC-1, reduced folate carrier - I;MDRI, multi-drug resistance - I;MTHFR, 5, 10-methylenetetrahydrofolate reductase (NADPH);TYMS, thymidylate synthetase; ATIC, 5-aminoimidazole-4-carboxamide ribonucleotide formyltransferase/IMP cyclohydrolase.

ies suggest that a variant in the SLC19A1 gene encoding RFC-1 (rs1051266; SLC19A1 80G>A) may influence MTX efficacy and toxicity in RA; ${ }^{114,115}$ a finding which has not been replicated in subsequent studies. ${ }^{116,117}$

MTHFR, a prominent regulatory enzyme involved in the folate pathway, catalyzes the conversion of 5,10-methylenetetrahydrofolate to 5-methyltetrahydrofolate, which is a substrate for homocysteine remethylation. While seven polymorphisms have been associated with MTX efficacy or toxicity, ${ }^{116,121}$ two nonsynonymous SNPs (rs1801133: 677C $>$ T and rs 1801131: 1289A $>$ C) have been extensively studied. The homozygous and heterozygous variants of the MTHFR $677 \mathrm{C}>\mathrm{T}$ polymorphism decreases enzyme activity by approximately $70 \%$ and $40 \%$, respectively. ${ }^{122,123}$ Similarly, the homozygous variant of the MTHFR $1298 \mathrm{~A}>\mathrm{C}$ variant has about $60 \%$ of wildtype function. ${ }^{124,125}$ Previous studies suggest that the MTHFR $677 \mathrm{C}>\mathrm{T}$ variant is not related to MTX efficacy, ${ }^{126,127}$ but rather plays a prominent role in toxicity. ${ }^{126,128,129}$ A recent meta-analysis of eight MTX studies, totaling over 1,400 RA patients for the MTHFR $677 \mathrm{C}>\mathrm{T}$ analysis, and over 660 for the $M T H F R 1298 \mathrm{~A}>\mathrm{C}$ analysis revealed that the $M T H F R$ 677C $>\mathrm{T}$ variant (ie, CT or TT genotype) was associated with increased toxicity $(\mathrm{OR}=1.71,95 \% \mathrm{CI}: 1.3-2.2 ; P<0.001) .{ }^{116}$ In contrast, the MTHFR $1298 \mathrm{~A}>\mathrm{C}$ variant was not associated with increased toxicity $(\mathrm{OR}=1.12,95 \% \mathrm{CI}: 0.8-1.6 ; P=$ 0.626). ${ }^{116}$ Unfortunately, the analysis was limited to these two variants due to a lack of sufficient data for other polymorphisms. Similarly, widely disparate definitions of efficacy among the MTX pharmacogenetic studies combined with insufficient data of MTX polymorphisms prevented meta-analysis of efficacy. ${ }^{116}$ 
The inter-individual variation in MTX dose required to gain clinical efficacy is highly variable and cannot be currently predicted. Likewise, we are unable to accurately predict which patients will develop ADRs. Given the complexity of the MTX pathway, it is highly probable that multiple genetic variants act in concert to predict MTX efficacy and/or toxicity. Interestingly, the formation of a pharmacogenetic index incorporating the additive effect of multiple genetic variants on MTX efficacy and toxicity may be a possible solution, which may ease the transition of MTX pharmacogenetic testing into the clinic. ${ }^{105}$ Indeed, there is evidence to suggest that a low pharmacogenetic index is associated with a good response to MTX, while a higher index score is associated with an increased incidence of ADRs. ${ }^{130,131}$

\section{Leflunomide}

Leflunomide is an immunomodulatory drug that inhibits the rate-limiting intracellular enzyme in the de novo synthesis of pyrimidines, which is crucial for activating lymphocytes. ${ }^{133}$ This DMARD is usually an alternative for MTX-intolerant or resistant RA patients. ${ }^{134}$ The main molecular target of leflunomide is dihydroorotate dehydrogenase (DHODH), a key enzyme of de novo pyrimidine synthesis. The human DHODH gene sequence is highly conserved and contains only one common missense polymorphism (rs3213422) located in the first exon of the $\mathrm{DHODH}$ gene $\left(19 \mathrm{C}>\mathrm{A}\right.$; Q7K). ${ }^{135}$ The frequency of remission was increased in $D H O D H 19 \mathrm{C}$ allele carriers compared with patients with the $D H O D H$ A allele indicating a potential role of the $\mathrm{DHODH}$ gene in leflunomide therapy. ${ }^{135}$ Consistent with in vitro studies, which demonstrated that $C Y P 1 A 2$ might be involved in leflunomide activation, RA patients with $C Y P 1 A 2 * 1 F C C$ genotype had a 9.7-fold higher risk for overall leflunomide-induced toxicity compared to carriers of $C Y P 1 A 2 * 1 F A$ allele $(\mathrm{OR}=9.7$; 95\% CI: $2.3-41.4 ; P=0.002) .{ }^{136}$ It has also been suggested that therapy with leflunomide causes decreased production of mediators such as IL- $1 \beta$, IL-6, and TNF- $\alpha$, which are involved in inflammatory process. ${ }^{137}$ However, IL-1 $\beta$, IL-6, and TNF- $\alpha$ gene variants appear to be insignificant factors influencing the therapy outcome of RA patients with leflunomide. ${ }^{137}$

\section{Azathioprine}

The immunosuppressant agent azathioprine (AZA) is a prodrug which is occasionally used in treating RA. ${ }^{138}$ However, treatment success is limited as $10 \%$ to $28 \%$ of patients terminate treatment due to ADRs, specifically myelosuppression. ${ }^{139,140}$ The thiopurine methyltransferase (TPMT) enzyme catalyzes the inactivation of purines, including
AZA, and it exhibits genetic polymorphism. ${ }^{141,142}$ Genetic polymorphism of TPMT is evident in all populations studied to date, including Caucasians, Asians, African-Americans, and Africans. TPMT*3A, TPMT*3C, and TPMT*2 are the most prevalent variant alleles comprising approximately 95\% of TPMT variant alleles in these populations. ${ }^{143-148}$ Genotyping for the three most studied SNPs (ie, $238 \mathrm{G}>\mathrm{C}$, $460 \mathrm{~A}>\mathrm{G}$, and $719 \mathrm{G}>\mathrm{A}$ ) provides greater than $95 \%$ concordance between TPMT genotype and phenotype. ${ }^{150,151}$ Briefly, approximately $90 \%$ of individuals inherit high activity, $10 \%$ have intermediate activity attributed to heterozygosity, and $0.3 \%$ have low or no detectable enzyme activity because they inherit two nonfunctional TPMT alleles. ${ }^{149}$ Multiple studies have demonstrated that TPMT-deficient patients and TPMT carriers are at high risk and an intermediate risk for severe hematological toxicity, respecitvely. ${ }^{152-154}$ Patients with intermediate TPMT activity should receive a reduction of approximately $50 \%$ of a normal AZA dose, while AZA should be avoided in patients with low or absent TPMT activity. ${ }^{155}$ A genotype-based dosing strategy is less costly, more effective, and is associated with a marked reduction in the number of serious ADRs compared to conventional weightbased dosing strategy. ${ }^{156}$ Support amongst rheumatologists for prospective TPMT genotyping continues to grow, due in part, to an accumulation of evidence supporting the use of genetic diagnostic testing.

\section{Sulfazalazine}

Sulfasalazine, a mildly potent DMARD used in the treatment of RA, inhibits neutrophil function, reduces immunoglobulin levels, and interferes with T-lymphocyte function via the suppression of NFKB. ${ }^{157}$ Polymorphisms within the gene encoding the N-acetyl transferase 2 (NAT2) enzyme affect the rate of acetylation which are thought to affect the efficacy and/or toxicity of sulfasalazine. ${ }^{158}$ RA patients lacking the wildtype haplotype (ie, $N A T 2 * 4$ ) at NAT2 appear to be more likely to suffer from overall ADRs (relative risk $[\mathrm{RR}]=3.31,95 \%$ CI: $1.8-6.2 ; P=0.001)$ and severe ADRs (RR $=24.6,95 \%$ CI: $2.4-254.5 ; P=0.015) .{ }^{158,159}$ Although additional studies are warranted, it is possible that, in the future, RA patients can be classified into groups according to NAT2 genotyping: rapid type (homozygote for $N A T 2 * 4$ ), intermediate type (heterozygote for $N A T 2 * 4$ and variant alleles), and slow type (homozygote for variant alleles). ${ }^{160}$

\section{TNF- $\alpha$ inhibitors}

Tumor necrosis factor- $\alpha$ (TNF- $\alpha$ ) blockade represents a major breakthrough in the treatment of RA. Controlled trials 
with all four anti-TNF- $\alpha$ agents, etanercept $\left(\right.$ Enbrel $\left.^{\circledR}\right)$, infliximab $\left(\right.$ Remicade $\left.^{\circledR}\right)$, golimumab (Simponi ${ }^{\mathrm{TM}}$ ), and adalimumab (Humira ${ }^{\circledR}$ ), presently approved for the treatment of RA, have demonstrated impressive improvement in most response measures, including clinical, laboratory and radiographic outcomes. ${ }^{161}$ Despite the marked improvement of symptoms and radiographic retardation of RA with the use of anti-TNF- $\alpha$ agents, randomized controlled trials reveal that only $60 \%$ to $70 \%$ of patients with moderate to severe RA achieve a satisfactory response. ${ }^{161}$ A lack of clinical and biochemical predictors of efficacy and toxicity of TNF inhibitors in RA patients has focused much attention to the affect of genetic variations on response. Candidate gene polymorphisms that affect response to etanercept or infliximab therapy are listed in Table 5. Although, multiple polymorphisms have been linked to response, the TNF- $\alpha$ gene promoter $-308 \mathrm{G}>\mathrm{A}$ variant (rs1800629) will be the focus of this review.

The functionality and thus relevance of the -308 variant to TNF- $\alpha$ treatment response is reflected by the ability of the
$T N F-\alpha(-308 \mathrm{~A})$ variant to influence the magnitude of the TNF- $\alpha$ secretory response ${ }^{162}$ and to affect circulating levels of TNF- $\alpha .{ }^{163}$ A recent meta-analysis of nine studies representing a total of 692 RA patients, demonstrated that the probability of successful treatment with anti-TNF- $\alpha$ agents is influenced, at least in part, by the variant in the $T N F-\alpha$ gene promoter region. ${ }^{164}$ The frequency of the $T N F-\alpha(-308 \mathrm{~A})$ variant was $22 \%$ in responders and $37 \%$ in nonresponders, and the OR was decreased in responders versus nonresponders $(\mathrm{OR}=0.4$, 95\% CI: $0.4-0.7 ; P=0.000245)$, irrespective of the TNF- $\alpha$ inhibitor prescribed. ${ }^{164}$ This is strong evidence indicating that the $T N F-\alpha(-308 \mathrm{~A})$ variant predicts poor response to TNF- $\alpha$ inhibitors. The clinical utility of prospectively genotyping for this variant when initiating anti-TNF- $\alpha$ therapy for RA should now be formally assessed. Moreover, it is conceivable that those with the $T N F-\alpha(-308 \mathrm{~A})$ variant could either be treated more aggressively with concomitant DMARDs or implement these biologics earlier in the therapeutic regimen. However, larger cohorts involving multiple centres and

Table 5 Influence of candidate genes on response to rheumatoid arthritis for patients receiving etanercept (ETA), infliximab (INF), or adalimumab (ADA) therapy

\begin{tabular}{|c|c|c|c|c|c|}
\hline $\begin{array}{l}\text { Candidate } \\
\text { gene(s) }\end{array}$ & $\begin{array}{l}\text { Sample } \\
\text { size }\end{array}$ & $\begin{array}{l}\text { Response } \\
\text { criteria }\end{array}$ & $\begin{array}{l}\text { Follow-up } \\
\text { time }\end{array}$ & $\begin{array}{l}\text { Genotype/phenotype } \\
\text { correlation }\end{array}$ & Ref. \\
\hline$T N F-\alpha(-238 G>A)$ & 40 & DAS28 & 6 months & $\begin{array}{l}\text { GA genotype is associated with } \\
\text { a negative response to INF }\end{array}$ & 169 \\
\hline \multirow[t]{2}{*}{ TNF- $\alpha(-857)$} & 70 & ACR20 & 3 months & $\begin{array}{l}\mathrm{CT} / \mathrm{TT} \text { genotypes are associated } \\
\text { with positive response to ETA }\end{array}$ & 170 \\
\hline & 58 & DAS28 & N/A & $\begin{array}{l}\mathrm{CC} \text { genotype is associated with positive } \\
\text { response to INF }\end{array}$ & 171 \\
\hline \multirow[t]{2}{*}{ TNFRII 676T>G } & 105 & ACR20 & 12 months & $\begin{array}{l}\text { TG genotype is associated with a negative } \\
\text { response to ETN, INF or ADA }\end{array}$ & 172 \\
\hline & 58 & DAS28 & N/A & $\begin{array}{l}\text { TT genotype is associated with positive } \\
\text { response in RA }\end{array}$ & $17 \mid$ \\
\hline FCGR3A $158 \mathrm{~F}>\mathrm{V}$ & 91 & ACR20 & 7.5 months & $\begin{array}{l}\text { FF genotype is associated with a positive } \\
\text { response to INF }\end{array}$ & 173 \\
\hline $\begin{array}{l}\text { TNF- } \alpha(-308 G>A) \& \text { IL- } 10 \\
(-1087 G>A) \text { combination }\end{array}$ & 123 & ACR20, DAS28 & 3 months & $\begin{array}{l}\text { GG genotype is associated with positive } \\
\text { response to ETA }\end{array}$ & 174 \\
\hline $\begin{array}{l}\text { IL-IRNVNTR and TGFBI } \\
915 G>C \text { Combination }\end{array}$ & 123 & ACR20, DAS28 & 3 months & $\begin{array}{l}\mathrm{A} 2 / \mathrm{C} \text { allele combination is associated } \\
\text { with negative response to ETA }\end{array}$ & 174 \\
\hline$H L A-D R B I$ & 255 & ACR50 & 12 months & $\begin{array}{l}* 0404 \& * 0101 \text { combination is associated } \\
\text { with positive response }\end{array}$ & 175 \\
\hline \multirow[t]{4}{*}{ IL-10 } & 50 & DAS28 & 48 months & IL-I0.R3 is associated with positive response & 176 \\
\hline & 50 & DAS28 & 48 months & $\begin{array}{l}\text { IL-I0.GI } 3 \text { is associated with moderate } \\
\text { or negative response }\end{array}$ & \\
\hline & 50 & DAS28 & 48 months & $\begin{array}{l}\text { IL-I0.R2 \& GI3 combination is associated } \\
\text { with moderate or negative response }\end{array}$ & \\
\hline & 50 & DAS28 & 48 months & $\begin{array}{l}\text { IL-I0.R3 \& G9 combination is associated } \\
\text { with positive response }\end{array}$ & \\
\hline
\end{tabular}

Abbreviations: ACR, American College of Rheumatology based on perceptual improvement (20,50,70, 90\%) in disease symptoms; DAS28, disease activity score in 28 joints; IL, interleukin; TNF- $\alpha$, tumor necrosis factor- $\alpha$. 
ethnicities are a prerequisite before definite conclusions can be drawn regarding the functional role of the TNF- $\alpha-308 \mathrm{~A}$ variant and response to TNF- $\alpha$ inhibitors.

With respect to expression profiling studies, Lequerre and colleagues set out to identify predictive genes that would determine responsiveness to infliximab in peripheral blood mononuclear cells (PBMCs) by examining 16 responders and 17 nonresponders to infliximab treatment. ${ }^{165}$ Forty-one transcripts discriminated infliximab responders from nonresponders, including CYP3A4, LAMR1, and KNG1. A subset of these transcripts were assessed in two new patients and a sensitivity of $90 \%$ and specificity of $70 \%$ was achieved for these transcripts. ${ }^{165}$

\section{IL-I antagonists}

Although clinical trials of human recombinant IL-1 receptor antagonists in treating RA have been successful, the magnitude of its effect is inferior to that of anti-TNF- $\alpha$ therapy in RA and varies among patients. ${ }^{166}$ The prominent role of IL-1 in the immune response combined with an apparent association between the $I L-1$ cluster genes and RA susceptibility suggests that this gene may also be related to the likelihood of response to anti-IL-1 therapy in RA patients. Indeed, Camp and colleagues reported that $I L-1$ gene does influence reduction in swollen joints in RA patients treated with an IL-1 receptor antagonist. ${ }^{167}$ A highly significant association was found between carriage of the rarer allele at $I L-1 A(+4845)$ and response to treatment $(\mathrm{OR}=4.8 ; 95 \%$ CI: $1.8-12.7 ; P=0.0009) .{ }^{167}$ Moreover, the response rate in patients carrying this allele was $63.4 \%$ compared with $26.3 \%$ in noncarriers. ${ }^{167}$ Due to the paucity of pharmacogenetic data on IL-1 receptor antagonists and other biologics (eg, IL-12/23 variants) in RA patients, much more research is warranted to better define the relationship between the $I L-1$ gene cluster and response to $\mathrm{IL}-1$ receptor antagonists.

\section{Conclusion}

Diagnostic testing using genetic markers is superior compared to testing with traditional biomarkers, such as markers of the inflammatory process (eg, C-reactive protein, cytokines) and markers of disease-associated autoantibodies (eg, rheumatoid factor, ACPA status) as they afford greater predictive power, drastically reduce the need for repeated biochemical testing and are less affected by environmental factors like diet. Whereas, traditional biomarkers are important helping to establish a clinical diagnosis, genetic markers can help identify high-risk individuals reliably and in a timely manner so that they can either be treated before onset of the disease or as soon as possible thereafter. For example, patients at high risk or who fail to respond to conservative therapy are candidates for earlier, more aggressive strategies using single or possibly combination antirheumatic therapy.

RA is a complex disease with considerable genetic heterogeneity. With the advent of GWAS, much progress has been made in the genetics of RA. However, the non-MHC RA risk alleles still account for only $5 \%$ of the overall genetic burden of RA, indicating that additional non-MHC risk alleles remain to be discovered. ${ }^{168}$ Likewise, the modest effect size and power of existing studies to detect these effects at genome-wide levels of significance indicates that many more common alleles of modest effect remain to be discovered. ${ }^{36}$ In the future, several steps are paramount in elucidating the genetics of RA in relation to improved patient care. Firstly, as sample sizes increase, coverage across the genome is improved and copy number variations are included, GWAS will reveal these common variants of modest risk, the so-called 'hidden' risk alleles. Secondly, in addition to identifying and confirming risk alleles, functional studies will be fundamental to better understand how these variants contribute to RA pathogenesis. Thirdly, it will be important to determine the value of RA risk alleles in providing clinical prediction among healthy individuals, those with early symptoms consistent with RA, and those with established disease. Finally, it will be important to determine whether combinations of risk alleles are able to subset patients into clinically meaningful categories, which would result in superior patient care.

Similar to pathogenesis, the genetics of RA pharmacotherapy is quite complex, with considerable variability in the cost and response to various medications. Likewise, many pharmacogenetic studies are often too small and the results of which can be inconsistent and misleading. The effect sizes are mild to modest, so there is limited clinical predictive value. However, there are some problems inherent to the field of pharmacogenetics. For this field to evolve further in RA, studies employing large genetically diverse cohorts, a standardized study design, and multiple genetic variants in concert, will be a prerequisite to accurately assess the impact of genetic variants on drug efficacy and/or toxicity. A priori knowledge of pharmacogenetic mechanisms associated with RA pharmacotherapy has to potential to identify and therefore stratify patients into clinically important treatment categories (ie, responders vs. nonresponders; tolerant vs intolerant). The incorporation of pharmacogenetics into clinical rheumatology practice (ie, personalized medicine) can certainly be a major 
advance in RA pharmacotherapy and a clear enhancement of patient care. However, for this to occur many more well executed and adequately powered studies are required.

It would be remiss to not briefly comment on the influence of epigenetic factors on RA pathogenesis. It has become increasingly evident that the influence of epigenetic processes on the development of rheumatic diseases is probably as strong as the genetic background of a patient. The combinatory nature of these processes forms a complex network of epigenetic modifications with the ability to regulate gene expression through activation or silencing of genes. Indeed, environmental triggers are involved in the development of RA as age, infections, smoking, nutrition, and pollution have been suggested to have an effect on the epigenetic background. Genome-wide analyses of the epigenome (eg, DNA methylation, histone modifications) will enable the detection of additional genes involved in the pathogenesis of rheumatoid arthritis. In the future, knowledge of the epigenetic processes combined with enhanced genetic information will be essential for the understanding of the differences seen in the clinical picture of patients with rheumatic diseases such as RA.

\section{Disclosures}

The authors report no conflicts of interest in this work.

\section{References}

1. Lee DM, Weinblatt ME. Rheumatoid arthritis. Lancet. 2001; 358(9285):903-911.

2. van Vollenhoven RF. Treatment of rheumatoid arthritis: state of the art 2009. Nat Rev Rheumatol. 2009;5(10):531-541.

3. McInnes IB, Schett G. Cytokines in the pathogenesis of rheumatoid arthritis. Nat Rev Immunol. 2007;7(6):429-442.

4. Seldin MF, Amos CI, Ward R, Gregersen PK. The genetics revolution and the assault on rheumatoid arthritis. Arthritis Rheum. 1999;42(6): 1071-1079.

5. MacGregor A, Snieder H, Rigby A, et al. Characterizing the quantitative genetic contribution to rheumatoid arthritis using data from twins. Arthritis Rheum. 2000;43(1):30-37.

6. Bowes J, Barton A. Recent advances in the genetics of RA susceptibility. Rheumatology. 2008;47(4):399-402.

7. Imboden JB. The immunopathogenesis of rheumatoid arthritis. Annu Rev Pathol. 2009;4:417-434.

8. Coenen MJ, Gregersen PK. Rheumatoid arthritis: a view of the current genetic landscape. Genes Immun. 2009;10(2):101-111.

9. Jun $\mathrm{KR}$, Choi SE, Cha $\mathrm{CH}$, et al. Meta-analysis of the association between HLA-DRB1 allele and rheumatoid arthritis susceptibility in Asian populations. J Korean Med Sci. 2007;22(6):973-980.

10. Lee HS, Lee AT, Criswell LA, et al. Several regions in the major histocompatibility complex confer risk for anti-CCP-antibody positive rheumatoid arthritis, independent of the DRB1 locus. Mol Med. 2008; 14(5-6):293-300.

11. Deighton CM, Walker DJ, Griffiths ID, Roberts DF. The contribution of HLA to rheumatoid arthritis. Clin Genet. 1989;36(3):178-182.

12. Huizinga TW, Amos CI, van der Helm-van Mil AH, et al. Refining the complex rheumatoid arthritis phenotype based on specificity of the HLA-DRB1 shared epitope for antibodies to citrullinated proteins. Arthritis Rheum. 2005;52(11):3433-3438.
13. Morgan AW, Haroon-Rashid L, Martin SG, et al. The shared epitope hypothesis in rheumatoid arthritis: evaluation of alternative classification criteria in a large UK Caucasian cohort. Arthritis Rheum. 2008;58(5):1275-1283.

14. Gregersen PK, Silver J, Winchester RJ. The shared epitope hypothesis. An approach to understanding the molecular genetics of susceptibility to rheumatoid arthritis. Arthritis Rheum. 1987;30(11):1205-1213.

15. van der Helm-van Mil AH, Wesoly JZ, Huizinga TW. Understanding the genetic contribution to rheumatoid arthritis. Curr Opin Rheumatol. 2005;17(3):299-304.

16. de Vries N, Tijssen H, van Riel PL, van de Putte LB. Reshaping the shared epitope hypothesis: HLA-associated risk for rheumatoid arthritis is encoded by amino acid substitutions at positions $67-74$ of the HLADRB1 molecule. Arthritis Rheum. 2002;46(4):921-928.

17. Newton JL, Harney SM, Wordsworth BP, Brown MA. A review of the MHC genetics of rheumatoid arthritis. Genes Immun. 2004;5(3): $151-157$.

18. Gonzalez-Gay MA, Garcia-Porrua C, Hajeer AH. Influence of human leukocyte antigen-DRB1 on the susceptibility and severity of rheumatoid arthritis. Semin Arthritis Rheum. 2002;31(6):355-360.

19. Stastny P. Association of the B-cell alloantigen DRw4 with rheumatoid arthritis. N Engl J Med. 1978;298(16):869-871.

20. Gorman JD, Lum RF, Chen JJ, Suarez-Almazor ME, Thomson G, Criswell LA. Impact of shared epitope genotype and ethnicity on erosive disease: a meta-analysis of 3,240 rheumatoid arthritis patients. Arthritis Rheum. 2004;50(2):400-412.

21. Ollier W, Thomson W. Population genetics of rheumatoid arthritis. Rheum Dis Clin North Am. 1992;18(4):741-759.

22. MacGregor A, Ollier W, Thomson W, Jawaheer D, Silman A. HLADRB1*0401/0404 genotype and rheumatoid arthritis: increased association in men, young age at onset, and disease severity. $J$ Rheumatol. 1995;22(6):1032-1036.

23. du Montcel ST, Michou L, Petit-Teixeira E, et al. New classification of HLA-DRB1 alleles supports the shared epitope hypothesis of rheumatoid arthritis susceptibility. Arthritis Rheum. 2005;52(4): 1063-1068.

24. Bridges SL Jr, Kelley JM, Hughes LB. The HLA-DRB1 shared epitope in Caucasians with rheumatoid arthritis: a lesson learned from tic-tac-toe. Arthritis Rheum. 2008;58(5):1211-1215.

25. Michou L, Croiseau P, Petit-Teixeira E, et al. Validation of the reshaped shared epitope HLA-DRB1 classification in rheumatoid arthritis. Arthritis Res Ther. 2006;8(3):R79.

26. Barnetche T, Constantin A, Cantagrel A, Cambon-Thomsen A, Gourraud PA. New classification of HLA-DRB1 alleles in rheumatoid arthritis susceptibility: a combined analysis of worldwide samples. Arthritis Res Ther. 2008;10(1):R26.

27. Irigoyen P, Lee AT, Wener MH, et al. Regulation of anti-cyclic citrullinated peptide antibodies in rheumatoid arthritis: contrasting effects of HLA-DR3 and the shared epitope alleles. Arthritis Rheum. 2005;52(12):3813-3818.

28. van der Helm-van Mil AH, Verpoort KN, Breedveld FC, Huizinga TW, Toes RE, de Vries RR. The HLA-DRB1 shared epitope alleles are primarily a risk factor for anti-cyclic citrullinated peptide antibodies and are not an independent risk factor for development of rheumatoid arthritis. Arthritis Rheum. 2006;54(4):1117-1121.

29. van der Helm-van Mil AH, Huizinga TW. Advances in the genetics of rheumatoid arthritis point to subclassification into distinct disease subsets. Arthritis Res Ther. 2008;10(2):205-212.

30. Ding B, Padyukov L, Lundström E, et al. Different patterns of associations with anti-citrullinated protein antibody-positive and anticitrullinated protein antibody-negative rheumatoid arthritis in the extended major histocompatibility complex region. Arthritis Rheum. 2009;60(1):30-38

31. Karlson EW, Chibnik LB, Cui J, et al. Associations between human leukocyte antigen, PTPN22, CTLA4 genotypes and rheumatoid arthritis phenotypes of autoantibody status, age at diagnosis and erosions in a large cohort study. Ann Rheum Dis. 2008;67(3):358-363. 
32. Nishimura K, Sugiyama D, Kogata Y, et al. Meta-analysis: diagnostic accuracy of anti-cyclic citrullinated peptide antibody and rheumatoid factor for rheumatoid arthritis. Ann Intern Med. 2007;146(11): 797-808.

33. Wu H, Khanna D, Park G, et al. Interaction between RANKL and HLADRB1 genotypes may contribute to younger age at onset of seropositive rheumatoid arthritis in an inception cohort. Arthritis Rheum. 2004; 50(10):3093-3103.

34. van Gaalen FA, van Aken J, Huizinga TW, et al. Association between HLA class II genes and autoantibodies to cyclic citrullinated peptides (CCPs) influences the severity of rheumatoid arthritis. Arthritis Rheum. 2004;50(7):2113-2121.

35. Begovich AB, Carlton VE, Honigberg LA, et al. A missense singlenucleotide polymorphism in a gene encoding a protein tyrosine phosphatase (PTPN22) is associated with rheumatoid arthritis. Am J Hum Genet. 2004;75(2):330-337.

36. Wellcome Trust Case Control Consortium. Genome-wide association study of 14,000 cases of seven common diseases and 3,000 shared controls. Nature. 2007;447(7145):661-678

37. Plenge RM, Padyukov L, Remmers EF, et al. Replication of putative candidate-gene associations with rheumatoid arthritis in $>4,000$ samples from North America and Sweden: association of susceptibility with PTPN22, CTLA4, and PADI4. Am J Hum Genet. 2005;77(6): 1044-1060.

38. Hinks A, Barton A, John S, et al. Association between the PTPN22 gene and rheumatoid arthritis and juvenile idiopathic arthritis in a UK population: further support that PTPN22 is an autoimmunity gene. Arthritis Rheum. 2005;52(6):1694-1699.

39. Seldin MF, Shigeta R, Laiho K, et al. Finnish case-control and family studies support PTPN22 R620W polymorphism as a risk factor in rheumatoid arthritis, but suggest only minimal or no effect in juvenile idiopathic arthritis. Genes Immun. 2005;6(8):720-722.

40. Pierer M, Kaltenhäuser S, Arnold S, et al. Association of PTPN22 1858 single-nucleotide polymorphism with rheumatoid arthritis in a German cohort: higher frequency of the risk allele in male compared to female patients. Arthritis Res Ther. 2006;8(3):R75.

41. Zhernakova A, Eerligh P, Wijmenga C, Barrera P, Roep BO, Koeleman BP. Differential association of the PTPN22 coding variant with autoimmune diseases in a Dutch population. Genes Immun. 2005;6(6): $459-461$.

42. Orozco G, Sánchez E, González-Gay MA, et al. Association of a functional single-nucleotide polymorphism of PTPN22, encoding lymphoid protein phosphatase, with rheumatoid arthritis and systemic lupus erythematosus. Arthritis Rheum. 2005;52(1):219-224.

43. Stark K, Rovenský J, Blazicková S, et al. Association of common polymorphisms in known susceptibility genes with rheumatoid arthritis in a Slovak population using osteoarthritis patients as controls. Arthritis Res Ther. 2009;11(3):R70.

44. Farago B, Talian GC, Komlosi K, et al. Protein tyrosine phosphatase gene C1858T allele confers risk for rheumatoid arthritis in Hungarian subjects. Rheumatol Int. 2009;29(7):793-796.

45. Hill RJ, Zozulya S, Lu YL, Ward K, Gishizky M, Jallal B. The lymphoid protein tyrosine phosphatase Lyp interacts with the adaptor molecule Grb2 and functions as a negative regulator of T-cell activation. Exp Hematol. 2002;30(3):237-244.

46. Vang T, Congia M, Macis MD, et al. Autoimmune-associated lymphoid tyrosine phosphatase is a gain-of-function variant. Nat Genet. 2005; 37(12):1317-1319.

47. Rieck M, Arechiga A, Onengut-Gumuscu S, Greenbaum C, Concannon P, Buckner JH. Genetic variation in PTPN22 corresponds to altered function of T and B lymphocytes. J Immunol. 2007;179(7): 4704-4710.

48. Remmers EF, Plenge RM, Lee AT, et al. STAT4 and the risk of rheumatoid arthritis and systemic lupus erythematosus. $N$ Engl J Med. 2007;357(10):977-986.

49. Lee YH, Woo JH, Choi SJ, Ji JD, Song GG. Association between the rs7574865 polymorphism of STAT4 and rheumatoid arthritis: a metaanalysis. Rheumatol Int. 2009 Jul 9. [Epub ahead of print].
50. Martínez A, Varadé J, Márquez A, et al. Association of the STAT4 gene with increased susceptibility for some immune-mediated diseases. Arthritis Rheum. 2008;58(9):2598-2602.

51. Zervou MI, Sidiropoulos P, Petraki E, et al. Association of a TRAF1 and a STAT4 gene polymorphism with increased risk for rheumatoid arthritis in a genetically homogeneous population. Hum Immunol. 2008;69(9):567-571.

52. Daha NA, Kurreeman FA, Marques RB, et al. Confirmation of STAT4, IL2/IL21, and CTLA4 polymorphisms in rheumatoid arthritis. Arthritis Rheum. 2009;60(5):1255-1260.

53. Stark K, Rovenský J, Blazicková S, et al. Association of common polymorphisms in known susceptibility genes with rheumatoid arthritis in a Slovak population using osteoarthritis patients as controls. Arthritis Res Ther. 2009;11(3):R70.

54. Ji JD, Lee WJ, Kong KA, et al. Association of STAT4 polymorphism with rheumatoid arthritis and systemic lupus erythematosus: a metaanalysis. Mol Biol Rep. 2010;37(1):141-147.

55. Orozco G, Alizadeh BZ, Delgado-Vega AM, et al. Association of STAT4 with rheumatoid arthritis: a replication study in three European populations. Arthritis Rheum. 2008;58(7):1974-1980.

56. Walker JG, Smith MD. The Jak-STAT pathway in rheumatoid arthritis. J Rheumatol. 2005;32(9):1650-1653.

57. Watford WT, Hissong BD, Bream JH, Kanno Y, Muul L, O'Shea JJ. Signaling by IL-12 and IL-23 and the immunoregulatory roles of STAT4. Immunol Rev. 2004;202:139-156.

58. Skapenko A, Leipe J, Lipsky PE, Schulze-Koops H. The role of the T cell in autoimmune inflammation. Arthritis Res Ther. 2005;7 Suppl 2:S4-S14.

59. Morinobu A, Gadina M, Strober W, et al. STAT4 serine phosphorylation is critical for IL-12-induced IFN-gamma production but not for cell proliferation. Proc Natl Acad Sci U S A. 2002;99(19):12281-12286.

60. Nishikomori R, Usui T, Wu CY, Morinobu A, O'Shea JJ, Strober W. Activated STAT4 has an essential role in Th1 differentiation and proliferation that is independent of its role in the maintenance of IL-12R beta 2 chain expression and signaling. J Immunol. 2002;169(8):4388-4398.

61. Mathur AN, Chang HC, Zisoulis DG, et al. Stat 3 and Stat4 direct development of IL-17-secreting Th cells. J Immunol. 2007;178(8):4901-4907.

62. Bettelli E, Oukka M, Kuchroo VK. T(H)-17 cells in the circle of immunity and autoimmunity. Nat Immunol. 2007;8(4):345-350.

63. Suzuki A, Yamada R, Chang X, et al. Functional haplotypes of PADI4, encoding citrullinating enzyme peptidylarginine deiminase 4, are associated with rheumatoid arthritis. Nat Genet. 2003;34(4):395-402.

64. Takata Y, Inoue H, Sato A, et al. Replication of reported genetic associations of PADI4, FCRL3, SLC22A4 and RUNX1 genes with rheumatoid arthritis: results of an independent Japanese population and evidence from meta-analysis of East Asian studies. J Hum Genet. 2008;53(2):163-173.

65. Martinez A, Valdivia A, Pascual-Salcedo D, et al. PADI4 polymorphisms are not associated with rheumatoid arthritis in the Spanish population. Rheumatology. 2005;44(10):1263-1266

66. Hoppe B, Häupl T, Gruber R, et al. Detailed analysis of the variability of peptidylarginine deiminase type 4 in German patients with rheumatoid arthritis: a case-control study. Arthritis Res Ther. 2006;8(2):R34.

67. Costenbader KH, Chang SC, De Vivo I, Plenge R, Karlson EW. Genetic polymorphisms in PTPN22, PADI-4, and CTLA-4 and risk for rheumatoid arthritis in two longitudinal cohort studies: evidence of gene-environment interactions with heavy cigarette smoking. Arthritis Res Ther. 2008;10(3):R52.

68. Hoppe B, Häupl T, Egerer K, et al. Influence of peptidylarginine deiminase type 4 genotype and shared epitope on clinical characteristics and autoantibody profile of rheumatoid arthritis. Ann Rheum Dis. 2009;68(6):898-903.

69. Harney SM, Meisel C, Sims AM, Woon PY, Wordsworth BP, Brown MA. Genetic and genomic studies of PADI4 in rheumatoid arthritis. Rheumatology. 2005;44(7):869-872.

70. Kang CP, Lee HS, Ju H, Cho H, Kang C, Bae SC. A functional haplotype of the PADI4 gene associated with increased rheumatoid arthritis susceptibility in Koreans. Arthritis Rheum. 2006;54(1):90-96. 
71. Burr ML, Naseem H, Hinks A, et al. PADI4 genotype is not associated with rheumatoid arthritis in a large UK Caucasian Population. Ann Rheum Dis. 2009 May 25. [Epub ahead of print].

72. Iwamoto T, Ikari K, Nakamura T, et al. Association between PADI4 and rheumatoid arthritis: a meta-analysis. Rheumatology. 2006;45(7): 804-807.

73. Lee YH, Rho YH, Choi SJ, Ji JD, Song GG. PADI4 polymorphisms and rheumatoid arthritis susceptibility: a meta-analysis. Rheumatol Int. 2007;27(9):827-833.

74. Hoppe B, Häupl T, Egerer K, et al. Influence of peptidylarginine deiminase type 4 genotype and shared epitope on clinical characteristics and autoantibody profile of rheumatoid arthritis. Ann Rheum Dis. 2009; 68(6):898-903.

75. Vossenaar ER, Després N, Lapointe E, et al. Rheumatoid arthritis specific anti-Sa antibodies target citrullinated vimentin. Arthritis Res Ther. 2004;6(2):R142-150.

76. Simon M, Girbal E, Sebbag M, et al. The cytokeratin filament-aggregating protein filaggrin is the target of the so-called "antikeratin antibodies," autoantibodies specific for rheumatoid arthritis. J Clin Invest. 1993; 92(3):1387-1393.

77. Masson-Bessière C, Sebbag M, Girbal-Neuhauser E, et al. The major synovial targets of the rheumatoid arthritis-specific antifilaggrin autoantibodies are deiminated forms of the alpha- and beta-chains of fibrin. J Immunol. 2001;166(6):4177-4184.

78. Lee CS, Lee YJ, Liu HF, et al. Association of CTLA4 gene A-G polymorphism with rheumatoid arthritis in Chinese. Clin Rheumatol. 2003;22(3):221-224.

79. Zhernakova A, Eerligh P, Barrera P, et al. CTLA4 is differentially associated with autoimmune diseases in the Dutch population. Hum Genet. 2005;118(1):58-66.

80. Suppiah V, O'Doherty C, Heggarty S, Patterson CC, Rooney M, Vandenbroeck K. The CTLA4 + 49A/G and CT60 polymorphisms and chronic inflammatory arthropathies in Northern Ireland. Exp Mol Pathol. 2006;80(2):141-146.

81. Vaidya B, Pearce SH, Charlton S, et al. An association between the CTLA4 exon 1 polymorphism and early rheumatoid arthritis with autoimmune endocrinopathies. Rheumatology. 2002;41(2): 180-183.

82. Rodríguez MR, Núñez-Roldán A, Aguilar F, Valenzuela A, García A, González-Escribano MF. Association of the CTLA4 3' untranslated region polymorphism with the susceptibility to rheumatoid arthritis. Hum Immunol. 2002;63(1):76-81.

83. Greenfield EA, Nguyen KA, Kuchroo VK. CD28/B7 costimulation: a review. Crit Rev Immunol. 1998;18(5):389-418.

84. Maxwell L, Singh JA. Abatacept for rheumatoid arthritis. Cochrane Database Syst Rev. 2009;4:CD007277.

85. Linsley PS, Nadler SG. The clinical utility of inhibiting CD28-mediated costimulation. Immunol Rev. 2009;229(1):307-321.

86. Goëb V, Buch MH, Vital EM, Emery P. Costimulation blockade in rheumatic diseases: where we are? Curr Opin Rheumatol. 2009;21(3): 244-250.

87. Thomson W, Barton A, Ke X, et al. Rheumatoid arthritis association at 6q23. Nat Genet. 2007;39(12):1431-1433.

88. Dieguez-Gonzalez R, Calaza M, Perez-Pampin E, et al. Analysis of TNFAIP3, a feedback inhibitor of nuclear factor-kappaB and the neighbor intergenic $6 \mathrm{q} 23$ region in rheumatoid arthritis susceptibility. Arthritis Res Ther. 2009;11(2):R42.

89. Stark K, Rovenský J, Blazicková S, et al. Association of common polymorphisms in known susceptibility genes with rheumatoid arthritis in a Slovak population using osteoarthritis patients as controls. Arthritis Res Ther. 2009;11(3):R70.

90. Han TU, Bang SY, Kang C, Bae SC. TRAF1 polymorphisms associated with rheumatoid arthritis susceptibility in Asians and in Caucasians. Arthritis Rheum. 2009;60(9):2577-2584.

91. Orozco G, Hinks A, Eyre S, et al. Combined effects of three independent SNPs greatly increase the risk estimate for RA at 6q23. Hum Mol Genet. 2009;18(14):2693-2699.
92. Patsopoulos NA, Ioannidis JP. Susceptibility variants for rheumatoid arthritis in the TRAF1-C5 and 6q23 loci: a meta-analysis. Ann Rheum Dis. 2009 May 15. [Epub ahead of print].

93. Plenge RM, Cotsapas C, Davies L, et al. Two independent alleles at $6 \mathrm{q} 23$ associated with risk of rheumatoid arthritis. Nat Genet. 2007;39(12):1477-1482.

94. Boone DL, Turer EE, Lee EG, et al. The ubiquitin-modifying enzyme A20 is required for termination of Toll-like receptor responses. Nat Immunol. 2004;5(10):1052-1060.

95. Plenge RM, Seielstad M, Padyukov L, et al. TRAF1-C5 as a risk locus for rheumatoid arthritis--a genomewide study. $N$ Engl J Med. 2007;357(12):1199-1209.

96. Sen R, Baltimore D. Multiple nuclear factors interact with the immunoglobulin enhancer sequences. Cell. 1986;46(5):705-716.

97. Toonen EJ, Barrera P, Radstake TR, et al. Gene expression profiling in rheumatoid arthritis: current concepts and future directions. Ann Rheum Dis. 2008;67(12):1663-1669.

98. Lequerré T, Bansard C, Vittecoq O, et al. Early and long-standing rheumatoid arthritis: distinct molecular signatures identified by geneexpression profiling in synovia. Arthritis Res Ther. 2009;11(3):R99.

99. Chehal MK, Granville DJ. Cytochrome p450 2C (CYP2C) in ischemic heart injury and vascular dysfunction. Can J Physiol Pharmacol. 2006;84(1):15-20.

100. Rettie AE, Wienkers LC, Gonzalez FJ, Trager WF, Korzekwa KR. Impaired (S)-warfarin metabolism catalysed by the R144C allelic variant of CYP2C9. Pharmacogenetics. 1994;4(1):39-42.

101. Chiba T, Sato K, Endo M, et al. Upper gastrointestinal disorders induced by non-steroidal anti-inflammatory drugs. Hepatogastroenterology. 2005;52(64):1134-1138.

102. Bouvy ML, Heerdink ER, Hoes AW, Leufkens HG. Effects of NSAIDs on the incidence of hospitalisations for renal dysfunction in users of ACE inhibitors. Drug Saf. 2003;26(13):983-989.

103. Pilotto A, Seripa D, Franceschi M, et al. Genetic susceptibility to nonsteroidal anti-inflammatory drug-related gastroduodenal bleeding: role of cytochrome P450 2C9 polymorphisms. Gastroenterology. 2007;133(2):465-471.

104. Criswell LA, Saag KG, Sems KM, et al. Moderate-term, low-dose corticosteroids for rheumatoid arthritis. Cochrane Database Syst Rev. 2000;2:CD001158

105. Stamp L, Roberts R, Kennedy M, Barclay M, O’Donnell J, Chapman P. The use of low dose methotrexate in rheumatoid arthritis - are we entering a new era of therapeutic drug monitoring and pharmacogenomics? Biomed Pharmacother. 2006;60(10):678-687.

106. Morand EF. New therapeutic target in inflammatory disease: macrophage migration inhibitory factor. Intern Med J. 2005;35(7): 419-426.

107. Vivarelli M, D’Urbano LE, Insalaco A, et al. Macrophage migration inhibitory factor (MIF) and oligoarticular juvenile idiopathic arthritis (o-JIA): association of MIF promoter polymorphisms with response to intra-articular glucocorticoids. Clin Exp Rheumatol. 2007; 25(5):775-781.

108. Griga T, Wilkens C, Wirkus N, Epplen J, Schmiegel W, Klein W. A polymorphism in the macrophage migration inhibitory factor gene is involved in the genetic predisposition of Crohn's disease and associated with cumulative steroid doses. Hepatogastroenterology. 2007;54(75):784-786.

109. Berdeli A, Mir S, Ozkayin N, Serdaroglu E, Tabel Y, Cura A. Association of macrophage migration inhibitory factor $-173 \mathrm{C}$ allele polymorphism with steroid resistance in children with nephrotic syndrome. Pediatr Nephrol. 2005;20(11):1566-1571.

110. Berdeli A, Ozyürek AR, Ulger Z, et al. Association of macrophage migration inhibitory factor gene $-173 \mathrm{G} / \mathrm{C}$ polymorphism with prognosis in Turkish children with juvenile rheumatoid arthritis. Rheumatol Int. 2006;26(8):726-731.

111. De Benedetti F, Meazza C, Vivarelli M, et al. Functional and prognostic relevance of the -173 polymorphism of the macrophage migration inhibitory factor gene in systemic-onset juvenile idiopathic arthritis. Arthritis Rheum. 2003;48(5):1398-1407. 
112. Radstake TR, Fransen J, Toonen EJ, et al. Macrophage migration inhibitory factor polymorphisms do not predict therapeutic response to glucocorticoids or to tumour necrosis factor alpha-neutralising treatments in rheumatoid arthritis. Ann Rheum Dis. 2007;66(11): $1525-1530$.

113. Cronstein BN. Low-dose methotrexate: a mainstay in the treatment of rheumatoid arthritis. Pharmacol Revi. 2005;57(2):163-172.

114. Dervieux T, Furst D, Lein DO, et al. Polyglutamation of methotrexate with common polymorphisms in reduced folate carrier, aminoimidazole carboxamide ribonucleotide transformylase, and thymidylate synthase are associated with methotrexate effects in rheumatoid arthritis. Arthritis Rheum. 2004;50(9):2766-2774.

115. Dervieux T, Kremer J, Lein DO, et al. Contribution of common polymorphisms in reduced folate carrier and gamma-glutamylhydrolase to methotrexate polyglutamate levels in patients with rheumatoid arthritis. Pharmacogenetics. 2004;14(11):733-739.

116. Fisher MC, Cronstein BN. Metaanalysis of methylenetetrahydrofolate reductase (MTHFR) polymorphisms affecting methotrexate toxicity. $J$ Rheumatol. 2009;36(3):539-545.

117. Wessels JA, de Vries-Bouwstra JK, Heijmans BT, et al. Efficacy and toxicity of methotrexate in early rheumatoid arthritis are associated with single-nucleotide polymorphisms in genes coding for folate pathway enzymes. Arthritis Rheum. 2006;54(4):1087-1095.

118. Bohanec Grabar P, Logar D, Lestan B, Dolzan V. Genetic determinants of methotrexate toxicity in rheumatoid arthritis patients: a study of polymorphisms affecting methotrexate transport and folate metabolism. Eur J Clin Pharmacol. 2008;64(11):1057-1068.

119. Drozdzik M, Rudas T, Pawlik A, et al. The effect of $3435 \mathrm{C}>\mathrm{T}$ MDR1 gene polymorphism on rheumatoid arthritis treatment with disease-modifying antirheumatic drugs. Eur J Clin Pharmacol. 2006; 62(11):933-937.

120. Pawlik A, Wrzesniewska J, Fiedorowicz-Fabrycy I, GawronskaSzklarz B. The MDR1 3435 polymorphism in patients with rheumatoid arthritis. Int J Clin Pharmacol Ther. 2004;42(9):496-503.

121. Rozen R. Molecular genetics of methylenetetrahydrofolate reductase deficiency. J Inherit Metab Dis. 1996;19(5):589-594.

122. Kang SS, Zhou J, Wong PW, Kowalisyn J, Strokosch G. Intermediate homocysteinemia: a thermolabile variant of methylenetetrahydrofolate reductase. Am J Hum Genet. 1988;43(4):414-421.

123. Frosst P, Blom HJ, Milos R, et al. A candidate genetic risk factor for vascular disease: a common mutation in methylenetetrahydrofolate reductase. Nat Genet. 1995;10(1):111-113.

124. van der Put NM, Gabreëls F, Stevens EM, et al. A second common mutation in the methylenetetrahydrofolate reductase gene: an additional risk factor for neural-tube defects? Am J Hum Genet. 1998;62(5): 1044-1051.

125. Ranganathan P, Eisen S, Yokoyama WM, McLeod HL. Will pharmacogenetics allow better prediction of methotrexate toxicity and efficacy in patients with rheumatoid arthritis? Ann Rheum Dis. 2003;62(1):4-9.

126. van Ede AE, Laan RF, Blom HJ, et al. The C677T mutation in the methylenetetrahydrofolate reductase gene: a genetic risk factor for methotrexate-related elevation of liver enzymes in rheumatoid arthritis patients. Arthritis Rheum. 2001;44(11):2525-2530.

127. Hughes LB, Beasley TM, Patel H, et al. Racial or ethnic differences in allele frequencies of single-nucleotide polymorphisms in the methylenetetrahydrofolate reductase gene and their influence on response to methotrexate in rheumatoid arthritis. Ann Rheum Dis. 2006;65(9):1213-1218.

128. Urano W, Taniguchi A, Yamanaka H, et al. Polymorphisms in the methylenetetrahydrofolate reductase gene were associated with both the efficacy and the toxicity of methotrexate used for the treatment of rheumatoid arthritis, as evidenced by single locus and haplotype analyses. Pharmacogenetics. 2002;12(3):183-190.

129. Berkun Y, Levartovsky D, Rubinow A, et al. Methotrexate related adverse effects in patients with rheumatoid arthritis are associated with the A1298C polymorphism of the MTHFR gene. Ann Rheum Dis. 2004;63(10):1227-1231.
130. Dervieux T, Furst D, Lein DO, et al. Pharmacogenetic and metabolite measurements are associated with clinical status in patients with rheumatoid arthritis treated with methotrexate: results of a multicentred cross sectional observational study. Ann Rheum Dis. 2005;64(8):1180-1185.

131. Weisman MH, Furst DE, Park GS, et al. Risk genotypes in folate-dependent enzymes and their association with methotrexate-related side effects in rheumatoid arthritis. Arthritis Rheum. 2006;54(2):607-612.

132. Kumagai K, Hiyama K, Oyama T, Maeda H, Kohno N. Polymorphisms in the thymidylate synthase and methylenetetrahydrofolate reductase genes and sensitivity to the low-dose methotrexate therapy in patients with rheumatoid arthritis. Int J Mol Med. 2003;11(5):593-600.

133. Olsen NJ, Stein CM. New drugs for rheumatoid arthritis. $N$ Engl J Med. 2004;350(21):2167-2179.

134. Maddison P, Kiely P, Kirkham B, et al. Leflunomide in rheumatoid arthritis: recommendations through a process of consensus. Rheumatology. 2005;44(3):280-286.

135. Pawlik A, Herczynska M, Kurzawski M, Safranow K, Dziedziejko V, Drozdzik M. The effect of exon $(19 \mathrm{C}>\mathrm{A})$ dihydroorotate dehydrogenase gene polymorphism on rheumatoid arthritis treatment with leflunomide. Pharmacogenomics. 2009;10(2):303-309.

136. Bohanec Grabar P, Rozman B, Tomsic M, Suput D, Logar D, Dolzan V. Genetic polymorphism of CYP1A2 and the toxicity of leflunomide treatment in rheumatoid arthritis patients. Eur J Clin Pharmacol. 2008;64(9):871-876.

137. Pawlik A, Herczyńska M, Kurzawski M, et al. IL-1beta, IL-6, and TNF gene polymorphisms do not affect the treatment outcome of rheumatoid arthritis patients with leflunomide. Pharmacol Rep. 2009;61(2):281-287.

138. Ahern MJ, Harrison W, Hollingsworth P, Bradley J, Laing B, Bayliss C. A randomised double-blind trial of cyclosporin and azathioprine in refractory rheumatoid arthritis. Aust N ZJ Med. 1991;21(6): 844-849.

139. Pawlik A, Herczynska M, Kurzawski M, Safranow K, Dziedziejko V, Drozdzik M. The effect of exon (19C>A) dihydroorotate dehydrogenase gene polymorphism on rheumatoid arthritis treatment with leflunomide. Pharmacogenomics. 2009;10(2):303-309.

140. Schwab M, Schäffeler E, Marx C, et al. Azathioprine therapy and adverse drug reactions in patients with inflammatory bowel disease: impact of thiopurine S-methyltransferase polymorphism. Pharmacogenetics. 2002;12(6):429-436.

141. Weinshilboum RM, Sladek SL. Mercaptopurine pharmacogenetics: monogenic inheritance of erythrocyte thiopurine methyltransferase activity. Am J Hum Genet. 1980;32(5):651-662.

142. McLeod HL, Krynetski EY, Relling MV, Evans WE. Genetic polymorphism of thiopurine methyltransferase and its clinical relevance for childhood acute lymphoblastic leukemia. Leukemia. 2000;14(4): 567-572.

143. Present DH, Meltzer SJ, Krumholz MP, Wolke A, Korelitz BI. 6-Mercaptopurine in the management of inflammatory bowel disease: short- and long-term toxicity. Ann Intern Med. 1989;111(8): 641-649.

144. Korelitz BI, Adler DJ, Mendelsohn RA, Sacknoff AL. Long-term experience with 6-mercaptopurine in the treatment of Crohn's disease. Am J Gastroenterol. 1993;88(8):1198-1205.

145. Candy S, Wright J, Gerber M, Adams G, Gerig M, Goodman R. A controlled double blind study of azathioprine in the management of Crohn's disease. Gut. 1995;37(5):674-678.

146. Lamers CB, Griffioen G, van Hogezand RA, Veenendaal RA. Azathioprine: an update on clinical efficacy and safety in inflammatory bowel disease. Scand J Gastroenterol Suppl. 1999;230:111-115.

147. Nielsen OH, Vainer B, Rask-Madsen J. Review article: the treatment of inflammatory bowel disease with 6-mercaptopurine or azathioprine. Aliment Pharmacol Ther. 2001;15(11):1699-1708.

148. Fraser AG, Orchard TR, Jewell DP. The efficacy of azathioprine for the treatment of inflammatory bowel disease: a 30 year review. Gut. 2002;50(4):485-489. 
149. Yates CR, Krynetski EY, Loennechen T, et al. Molecular diagnosis of thiopurine S-methyltransferase deficiency: genetic basis for azathioprine and mercaptopurine intolerance. Ann Intern Med. 1997; 126(8):608-614.

150. Coulthard SA, Howell C, Robson J, Hall AG. The relationship between thiopurine methyltransferase activity and genotype in blasts from patients with acute leukemia. Blood. 1998;92(8):2856-2862.

151. Rossi AM, Bianchi M, Guarnieri C, Barale R, Pacifici GM. Genotypephenotype correlation for thiopurine S-methyltransferase in healthy Italian subjects. Eur J Clin Pharmacol. 2001;57(1):51-54.

152. Evans WE. Pharmacogenetics of thiopurine S-methyltransferase and thiopurine therapy. Ther Drug Monit. 2004;26(2):186-191.

153. Black AJ, McLeod HL, Capell HA, et al. Thiopurine methyltransferase genotype predicts therapy-limiting severe toxicity from azathioprine. Ann Intern Med. 1998;129(9):716-718.

154. Relling MV, Hancock ML, Rivera GK, et al. Mercaptopurine therapy intolerance and heterozygosity at the thiopurine S-methyltransferase gene locus. J Natl Cancer Inst. 1999;91(23):2001-2008.

155. Sandborn WJ. Rational dosing of azathioprine and 6-mercaptopurine Gut. 2001;48(5):591-592.

156. Oh KT, Anis AH, Bae SC. Pharmacoeconomic analysis of thiopurine methyltransferase polymorphism screening by polymerase chain reaction for treatment with azathioprine in Korea. Rheumatology. 2004; 43(2):156-163.

157. Gadangi P, Longaker M, Naime D, et al. The anti-inflammatory mechanism of sulfasalazine is related to adenosine release at inflamed sites. J Immunol. 1996;156(5):1937-1941.

158. Ladero JM. Influence of polymorphic N-acetyltransferases on nonmalignant spontaneous disorders and on response to drugs. Curr Drug Metab. 2008;9(6):532-537.

159. Taniguchi A, Urano W, Tanaka E, et al. Validation of the associations between single nucleotide polymorphisms or haplotypes and responses to disease-modifying antirheumatic drugs in patients with rheumatoid arthritis: a proposal for prospective pharmacogenomic study in clinical practice. Pharmacogenet Genomics. 2007;17(6):383-390.

160. Kumagai S, Komada F, Kita T, et al. N-acetyltransferase 2 genotyperelated efficacy of sulfasalazine in patients with rheumatoid arthritis. Pharm Res. 2004;21(2):324-329.

161. Furst DE, Breedveld FC, Kalden JR, et al. Updated consensus statement on biological agents, specifically tumour necrosis factor $\{$ alpha $\}$ (TNF $\{$ alpha $\}$ ) blocking agents and interleukin-1 receptor antagonist (IL-1 ra), for the treatment of rheumatic diseases, 2005. Ann Rheum Dis. 2005;64 Suppl 4:iv2-14.

162. Louis E, Franchimont D, Piron A, et al. Tumour necrosis factor (TNF) gene polymorphism influences TNF-alpha production in lipopolysaccharide (LPS)-stimulated whole blood cell culture in healthy humans. Clin Exp Immunol. 1998;113(3):401-406.

163. Cuchacovich M, Soto L, Edwardes M, et al. Tumour necrosis factor (TNF)alpha $-308 \mathrm{G} / \mathrm{G}$ promoter polymorphism and TNFalpha levels correlate with a better response to adalimumab in patients with rheumatoid arthritis. Scand J Rheumatoli. 2006;35(6):435-440.
164. O'Rielly DD, Roslin NM, Beyene J, Pope A, Rahman P. TNF-alpha-308 $\mathrm{G} /$ A polymorphism and responsiveness to TNF-alpha blockade therapy in moderate to severe rheumatoid arthritis: a systematic review and meta-analysis. Pharmacogenomics J. 2009;9(3):161-167.

165. Lequerré T, Gauthier-Jauneau AC, Bansard C, et al. Gene profiling in white blood cells predicts infliximab responsiveness in rheumatoid arthritis. Arthritis Res Ther. 2006;8(4):R105.

166. Bresnihan B, Alvaro-Gracia JM, Cobby M, et al. Treatment of rheumatoid arthritis with recombinant human interleukin-1 receptor antagonist. Arthritis Rheum. 1998;41(12):2196-2204.

167. Camp NJ, Cox A, di Giovine FS, McCabe D, Rich W, Duff GW. Evidence of a pharmacogenomic response to interleukin-1 receptor antagonist in rheumatoid arthritis. Genes Immun. 2005;6(6):467-471.

168. Plenge RM. Recent progress in rheumatoid arthritis genetics: one step towards improved patient care. Curr Opin Rheumatol. 2009;21(3): $262-271$.

169. Maxwell JR, Potter C, Hyrich KL, et al. Association of the tumour necrosis factor-308 variant with differential response to anti-TNF agents in the treatment of rheumatoid arthritis. Hum Mol Genet. 2008;17(22):3532-3538.

170. Kang CP, Lee KW, Yoo DH, Kang C, Bae SC. The influence of a polymorphism at position -857 of the tumour necrosis factor alpha gene on clinical response to etanercept therapy in rheumatoid arthritis. Rheumatology. 2005;44(4):547-552.

171. Chatzikyriakidou A, Georgiou I, Voulgari PV, Venetsanopoulou AI, Drosos AA. Combined tumour necrosis factor-alpha and tumour necrosis factor receptor genotypes could predict rheumatoid arthritis patients' response to anti-TNF-alpha therapy and explain controversies of studies based on a single polymorphism. Rheumatology (Oxford). 2007;46(6):1034-1035.

172. Ongaro A, De Mattei M, Pellati A, et al. Can tumor necrosis factor receptor II gene $676 \mathrm{~T}>\mathrm{G}$ polymorphism predict the response grading to anti-TNFalpha therapy in rheumatoid arthritis? Rheumatol Int. 2008; 28(9):901-908.

173. Cañete JD, Suárez B, Hernández MV, et al. Influence of variants of Fc gamma receptors IIA and IIIA on the American College of Rheumatology and European League Against Rheumatism responses to anti-tumour necrosis factor alpha therapy in rheumatoid arthritis. Ann Rheum Dis. 2009;68(10):1547-1552.

174. Padyukov L, Lampa J, Heimbürger M, et al. Genetic markers for the efficacy of tumour necrosis factor blocking therapy in rheumatoid arthritis. Ann Rheum Dis. 2003;62(6):526-529.

175. Criswell LA, Lum RF, Turner KN, et al. The influence of genetic variation in the HLA-DRB1 and LTA-TNF regions on the response to treatment of early rheumatoid arthritis with methotrexate or etanercept. Arthritis Rheum. 2004;50(9):2750-2756.

176. Schotte H, Schlüter B, Drynda S, et al. Interleukin 10 promoter microsatellite polymorphisms are associated with response to long term treatment with etanercept in patients with rheumatoid arthritis. Ann Rheum Dis. 2005;64(4):575-581.
Pharmacogenomics and Personalized Medicine

\section{Publish your work in this journal}

Pharmacogenomics and Personalized Medicine is an international, peer-reviewed, open access journal characterizing the influence of genotype on pharmacology leading to the development of personalized treatment programs and individualized drug selection for improved safety, efficacy and sustainability. This journal is indexed on the

\section{Dovepress}

American Chemical Society's Chemical Abstracts Service (CAS). The manuscript management system is completely online and includes a very quick and fair peer-review system, which is all easy to use. Visit http://www.dovepress.com/testimonials.php to read real quotes from published authors. 